\title{
In Search of a Second Chance: Channeling BMW $v$. Gore and Reconsidering Occupational Licensing Restrictions
}

\author{
Lahny R. Silva*
}

\section{INTRODUCTION}

In the early 1980s, Mr. Harry Darks and his partner Mr. Andre Milton applied for a license to operate a dance hall in Cincinnati. ${ }^{1}$ The hall, called London Hall, was to operate as a disco club on weekend nights between 11:00 P.M. and 5:00 A.M. ${ }^{2}$ Liquor licenses were not available and Darks and Milton purposely chose those hours to avoid competition with other halls and clubs that did serve liquor. ${ }^{3}$ To Mr. Darks's surprise, the City of Cincinnati summarily denied him the license to operate the hall. ${ }^{4}$ The reason underlying the denial was that Mr. Darks had been previously convicted of two felonies to which he pleaded guilty. ${ }^{5}$ Mr. Darks sued the City of Cincinnati claiming "that the City's licensing policy deprived [him] of equal protection and due process of law." 6 The district court granted summary judgment in favor of the city. ${ }^{7}$

\footnotetext{
Associate Professor of Law, Indiana University Robert H. McKinney School of Law. I would like to extend gratitude and special thanks to the University of Wisconsin Law School and those who participated in the Hastie Fellowship Reunion (2010) including Professor Peter Carstensen. Many thanks also to the SW/SE/MW 2010 People of Color Conference with special thanks to Charlton Copeland and Osamudia James. Also, I owe significant thanks to the faculty at Indiana University Robert H. McKinney School of Law including Professor Carlton Waterhouse, Professor George Wright, Professor Margaret Tarkington, and Professor Nicolas Terry. And, of course, thank you to my mentor Kaaryn Gustafson for all of your support and helpful comments.

1. Darks v. City of Cincinnati, 745 F.2d 1040, 1041 n.1 (6th Cir. 1984).

2. Id.

3. Id.

4. Id. at 1041 .

5. Id. at 1042; see Indictment and Plea, Ohio v. Darks, No. 85959 (Ohio Sup. Ct., Hamilton Cnty. 1965) (on file with author). Research for this Article discovered only one state felony conviction. Darks pleaded guilty to one felony count of receiving and concealing stolen goods, namely a stereo “Hi-Fi” Radio worth \$375 in Hamilton County, Ohio in 1965.

6. Darks, 745 F.2d at 1041.

7. Id.
} 
Appealing the district court's judgment, Darks continued to allege equal protection and due process violations. ${ }^{8}$ On the equal protection claim, Darks specifically argued that Cincinnati's "practice of denying dance hall licenses to all convicted felons deprived him of equal protection of the laws." "The municipal code of Cincinnati "provide[d] that licenses shall be issued only to 'reputable person[s] of good moral character.",10 On the due process claim, Darks asserted "that he was deprived of a liberty interest without due process of law because [Cincinnati's] practice of denying licenses to felons on the grounds that they are not persons of good character amounts to an irrebuttable presumption."11

The Court of Appeals for the Sixth Circuit decided that Cincinnati's policy of wholesale denial of licenses to convicted felons was constitutionally permissible. ${ }^{12}$ Quoting the District Court, the Sixth Circuit agreed that,

[T] he denial of dance hall licenses to convicted felons is rationally related to the legitimate state interest of insuring that such halls are operated by persons of integrity with a respect for the law, and insuring that they do not attract a criminal or other disreputable clientele. It is rational to connect a past felony conviction with a disrespect for the law and a lack of moral integrity. It is also rational to conclude that patrons exhibiting these traits would be more welcome at dance halls operated by those of like disposition than at dance halls operated by those without a past criminal record.

The Sixth Circuit made no distinction between crimes of moral turpitude and other crimes. ${ }^{14}$ Instead, it affirmed the lower court's judgment that wholesale discrimination against individuals with felony convictions was constitutionally permissible under the Equal Protection Clause of the Fourteenth Amendment. ${ }^{15}$ With regard to Darks's due process allegations, the court dismissed the argument. For the court, Cincinnati's licensing policy was a "substantive law" that passes rational basis

\footnotetext{
8. Id.

9. Id. at 1042 .

10. Id. (second alteration in original).

11. Id. at 1044 .

12. Id. at 1044.

13. Id. (alteration in original).

14. See id. at 1042-44 (discussing the denial of various licenses to felons without distinguishing between the kinds of offenses for which they were convicted).

15. Id. at 1044 .
} 
scrutiny and therefore is immune to constitutional attack. ${ }^{16}$ Although Darks pleaded guilty to the offenses without advisement from counsel or warning that he would be denied future occupational licenses, the court found no due process violations. ${ }^{17}$

A few years after the Sixth Circuit's opinion in Darks v. City of Cincinnati, Dr. Ira Gore purchased what he believed to be a brand-new black BMW sedan for \$40,750.88 from a Birmingham, Alabama BMW dealer. ${ }^{18}$ Nine months later, he took the car to "Slick Finish," a car detailer, for the purposes of making his new BMW look "snazzier than it normally would appear."19 The owner of the detailing company, Mr.

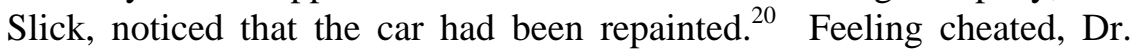
Gore sued BMW alleging that BMW had defrauded him by failing to disclose that the car had been repainted. ${ }^{21}$ An Alabama jury agreed, finding BMW liable for $\$ 4,000$ in compensatory damages ${ }^{22}$ and also finding that BMW's nondisclosure policy constituted "gross, oppressive, [and] malicious” fraud, thereby granting Dr. Gore $\$ 4$ million in punitive damages. $^{23}$ The Alabama Supreme Court reduced the award to \$2 million to make it "constitutionally reasonable.", 24

Six years later the United States Supreme Court held Dr. Gore’s \$2 million punitive damages award "grossly excessive." 25 Finding that BMW "did not receive adequate notice of the magnitude of the sanction”26 that might be imposed by the State of Alabama, the Court

16. See id. at 1043-44 (stating that the ordinance had rational basis support and thus did not violate the Equal Protection Clause).

17. Id. at 1044 .

18. See BMW of N. Am. v. Gore, 517 U.S. 559, 563 (1996).

19. Id. (quoting BMW of N. Am. v. Gore, 646 So. 2d 619, 621 (Ala. 1994), rev'd, 517 U.S. 559 (1996)).

20. Id.

21. See id. at 563 \& n.3 (stating Dr. Gore argued that the failure to disclose that the car had been repainted constituted the "suppression of a material fact").

22. Id. at 565. Dr. Gore sued BMW for $\$ 500,000$ in compensatory and punitive damages. Id. at 563. At trial he claimed $\$ 4,000$ in actual damages proven through the testimony of a BMW dealer. Id. at 564 . The dealer testified that a repainted BMW was valued at $10 \%$ less than a brand new BMW. Id.

23. Id. (quoting ALA. CoDE §§ 6-11-20 to -21 (1993)). To prove punitive damages, Dr. Gore provided evidence that BMW had sold close to 1,000 repainted cars in the United States in the preceding seven years. Id. With that, Dr. Gore assessed the appropriate punitive damages award at $\$ 4$ million, the value of his actual damages multiplied by the number of repainted cars BMW sold. Id.

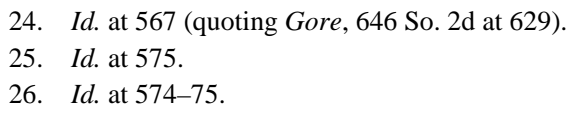


held the judgment violative of due process. ${ }^{27}$ For the Court, "[e]lementary notions of fairness enshrined in our constitutional jurisprudence dictate[d] that a person receive fair notice not only of the conduct that will subject him to punishment, but also of the severity of the penalty that a state may impose.”28 Although BMW is a multibilliondollar corporation with a number of U.S. corporate offices complete with in-house counsel that could have easily researched and informed the company of the punitive damages laws in the fifty states, ${ }^{29}$ the Court determined that BMW did not receive fair notice that a first violation of the Alabama Deceptive Practices Act would subject it to a multimilliondollar punitive damages judgment. ${ }^{30}$

Unlike the substantive due process review granted to BMW, Mr. Darks, our potential dance hall licensee, received no hearing, nor was he allowed to rebut Cincinnati's presumption that felony convictions demonstrate the felon's lack of moral integrity and disrespect for the law. Even if Mr. Darks received the chance, the irrebuttable presumption doctrine would offer him no relief as the Supreme Court has reasoned away any protection under that doctrine. ${ }^{31}$ Mr. Darks was also not entitled to proportionality review balancing his crimes-nonviolent offenses_-against the potential lifetime licensing disqualification. Moreover, there was no pragmatic consideration of Mr. Darks's practical ability to "know" or have "fair notice" of potential state penalties that attach to the status of "felon." In other words, how was Mr. Darks to know that because of his past felonies he would be stricken from participating in the economy in the future? Trial courts are not constitutionally required to include a warning of the employment consequences of conviction during a plea colloquy. ${ }^{32}$ Neither is defense counsel mandated to warn her client of these penalties. ${ }^{33}$

27. Id. at 575 .

28. Id. at 574 (emphasis added).

29. Company Information, BMW N. AM., http://www.bmwusa.com/Standard/Content/ CompanyInformation/BMWGroupinNA.aspx (last visited Oct. 2, 2012).

30. Gore, 517 U.S. at 585.

31. See, e.g., Michael H. v. Gerald D., 491 U.S. 110, 119-20 (1989) (denying the right to a hearing in a paternity case where it was the state's substantive policy to deny inquiries into "paternity that would be destructive of family integrity and privacy.").

32. United States v. Cariola, 323 F.2d 180, 186 (3d Cir. 1963) (listing several areas in which collateral consequences can have important legal significance, but also stating that a "full understanding" of the consequences of a guilty plea is not understood to mean a contemporaneous realization by the defendant of all possible collateral consequences).

33. Id. 
Today there are approximately 38,000 statutory and regulatory disqualifications triggered solely by the fact of prior felony conviction. ${ }^{34}$ This amounts to an average of 700 per jurisdiction, and it is estimated that $65 \%$ of these are employment related. ${ }^{35}$ This statutory phenomenon is typically called "collateral consequences" 36 and has been discussed among scholars in the academy for the last twenty years.

To date, numerous challenges have been brought contesting both occupational license restrictions and employment disqualifications. Equal protection challenges almost always fail. Because felons are not a suspect class and employment and occupational freedom are not "fundamental right[s]," the balancing test typically weighs in favor of the state, with the court finding a state's legitimate interest in "safety" or "health" outweighing the individual's interest in earning a livelihood. ${ }^{37}$ Due process challenges have also been levied against employment and licensing restrictions. Procedural due process challenges typically fail because courts presume notice and defer to state legislatures to determine the type and scope of discretion to give department employees in making licensing decisions. ${ }^{38}$ Although there are a few exceptions, most courts do not find in favor of the ex-offender even if the statute or regulation is obviously unfair, irrational, and overinclusive. ${ }^{39}$ With this, it is time to look for other avenues by which to challenge occupational collateral consequences of a felony conviction. In an era of mass incarceration, historically high rates of criminal recidivism, and massive government expenditures on crime and punishment, a focus on the occupational and employment opportunities of ex-offenders translates into taxpayer

34. Christopher Gowen et al., The ABA's Approach to Juvenile Justice Reform: Education, Eviction, and Employment: The Collateral Consequences of Juvenile Adjudications, A.B.A. CRIM. JUST. SEC., June 2011, at 1, 1-2, http://www.americanbar.org/content/dam/aba/publications/criminal justice/jj_gowen.authcheckdam.doc.

35. Id. at 2.

36. Gabriel J. Chin, Race, the War on Drugs, and the Collateral Consequences of Criminal Conviction, 6 J. GENDER RACE \& JUST. 253, 253 (2002).

37. In no way am I asserting that all collateral consequences are substantively bad. It is quite clear that in some instances governments should prohibit individuals convicted of specific crimes from engaging in certain occupations to protect the safety and welfare of their citizens, such as preventing individuals with a history of sex offenses from driving a school bus. It should also be clear that I assert that, if this is the case, then an individual pleading guilty to an offense ought to be warned by the court that she will be disqualified from this specific occupation.

38. See, e.g., Bhalero v. Ill. Dep’t of Fin. \& Prof'l Regs., 834 F. Supp. 2d. 775, 787 (N.D. Ill. 2011) (finding that a physician who had his license reprimanded due to a misdemeanor conviction received due process from licensing board in part because of the process afforded him at his criminal trial).

39. See, e.g., Darks v. City of Cincinnati, 745 F.2d 1040, 1044 (6th Cir. 1984). 
savings, an increase in state and federal revenue, and a more productive citizenry.

This Article advocates for reform of the current occupational licensing policies of the several states on behalf of the nonviolent offender. The additional restrictions and special conditions presented by violent offenders, sex offenders, and immigrant populations are beyond the scope of this Article. For purposes of this Article, the definition of "nonviolent" is the inverse definition of "violent" taken from the Armed Career Criminal Act. ${ }^{40}$ I chose this Act due to the congressional guidance it offers regarding the legislative intent on legal elements that define nonviolent offenses. Thus, a nonviolent offender is an individual who has been convicted of a crime that does not have an element requiring "the use, attempted use, or threatened use of physical force against the person of another." 41 This includes individuals convicted of smaller property crimes and drug trafficking, drug possession, or both. The current focus on nonviolent offenders also has an economic savings component. Current estimates of the U.S. prison population demonstrate that nonviolent offenders comprise at least half of all American inmates. $^{42}$ Recommendations in this article would have quite a significant impact not only on a number of nonviolent ex-offenders, but also on government expenditures and taxpayer savings. Finally, it is critical to understand that this thesis focuses on the ex-offender who garners a felony conviction through plea bargaining as opposed to conviction by criminal trial. This is significant as this thesis understands plea bargaining as a process in which the ex-offender must carefully weigh and consider all information regarding sanctions and penalties to make a rational choice. Without all of the information up front, an exoffender will fail to understand the severity of the penalties she faces outside of the criminal context.

40. The Pew Ctr. on the States, State of Recidivism: The Revolving Door of AMERICA's PRISONS (Apr. 2011) [hereinafter PEW CtR., STATE OF RECIDIVISM], http://www.pewstates.org/uploadedFiles/PCS_Assets/2011/Pew_State_of_Recidivism.pdf; THE PEW CTR. ON THE STATES, ONE IN 100: BEHIND BARS IN AMERICA 2008, at 6 (Feb. 2008) [hereinafter PEW CTR., ONE IN 100], http://www.pewstates.org/uploadedFiles/PCS_Assets/2008/one\%20in\% 20100.pdf; MATTHEW R. DUROSE \& Christopher J. MuMOLA, U.S. DEP’T OF JUSTICE, BUREAU OF Justice Statistics, Fact SheEt: Profile of Nonviolent Offenders Exiting State Prisons (Oct. 2004), http://bjs.ojp.usdoj.gov/content/pub/pdf/pnoesp.pdf.

41. See Armed Career Criminal Act of 1984, 18 U.S.C. § 924(c)(3)(A) (2006) (listing felonies that do not qualify as serious violent felonies for purposes of sentencing).

42. Paul Guerino et al., U.S. Dep’t. of Justice, Bureau of Justice Statistics, PRISONERS IN 2010, at 1 (Dec. 2011), http://bjs.ojp.usdoj.gov/content/pub/pdf/p10.pdf 
This Article applies recent Supreme Court jurisprudence in the area of punitive damages to that of occupational licensing restrictions triggered by a felony conviction. By using the framework constructed to evaluate the constitutionality of large punitive damages awards and applying those principles to occupational licensing statutes, it becomes clear that many occupational licensing statutes disqualifying those individuals with a prior felony conviction are constitutionally suspect. This Article adds to the scholarly debate by attempting to construct a solution founded in principles used to evaluate constitutional issues in the punitive damages context. Much of the existing literature focuses on the problems of mass incarceration, collateral consequences, and expenditures on recidivism. This Article understands this problem exists and is interested in uncovering potential constitutional challenges to these burgeoning socioeconomic issues.

Part II of this Article examines the problem, namely an incarceration crisis exacerbated by the revolving door of criminal recidivism. This section also includes a partial solution to this problem: employment of ex-offenders. Part III places the issue in context by surveying current constitutional doctrine regarding an individual's occupational freedoms, how the Supreme Court has handled collateral consequences in other contexts, precedent on the constitutionality of occupational licensing restrictions based on felony convictions, and the current constitutional challenges that have been tried and failed on this exact issue. Current doctrine is mixed and opaque at best. Part IV discusses the way in which $B M W$ v. Gore, a highly criticized Supreme Court opinion, can be used to ameliorate many of the severe and often irrational occupational licensing and employment disqualifications based solely on the fact of conviction. This section argues that the framework and principles crafted in BMW $v$. Gore and its progeny ought to have the ability to transcend punitive damages and apply successfully to other areas of constitutional concern in the civil context. To fully demonstrate the analysis, Part IV employs a hypothetical based on a Wisconsin occupational licensing regulation. Part V assesses counterarguments to this line of reasoning including the idea that the reform of occupational and employment disqualifications ought to be left to legislatures, and that challenges to such statutes should be brought under the Eighth or Sixth Amendments instead of due process. Finally, this Article concludes with a brief summary and thoughts of next steps in the challenge against occupational and employment disqualifications for nonviolent ex-offenders. 


\section{EMPLOYMENT CONSEQUENCES OF CONVICTION}

Something as simple as checking a box indicating a conviction bars a person from employment, housing, educational assistance, and government benefits. The employment consequences of conviction take the form of automatic or discretionary disqualifications in the public and private sectors. ${ }^{43}$

The theoretical underpinnings of these penalties are considered as preventing crime and providing a denunciatory purpose and retributive function. ${ }^{44}$ These abstract justifications do less to serve the stated objectives and more to provide a strong argument for the designation of collateral consequences as part of the sentencing court's punishment for the original offense. ${ }^{45}$ Moreover, this "web" of obstacles significantly contributes to the current recidivism rate. ${ }^{46}$ The ex-offender faces a double penalty: she pays her debt through incarceration and further pays through loss of life opportunity. ${ }^{47}$ This opportunity cost is socioeconomic, political, and seemingly never ending.

Employment is fundamental to the American identity. It is a prerequisite to membership in American society ${ }^{48}$ and is essential to the survival of the American family. An individual who fails to join the labor market is socioeconomically disadvantaged, stigmatized, and socially marred. ${ }^{49}$ Any serious departure from current "mass incarceration policies will ultimately depend on the expansion of employment opportunities for low-skilled [new releasees], and a reinvigoration of the moral status of these men in the political debate."

43. Michael Pinard \& Anthony C. Thompson, Offender Reentry and the Collateral Consequences of Criminal Convictions: An Introduction, 30 N.Y.U. REV. L. \& Soc. ChANGE 585, 595-98 (2006); Jeremy Travis, Invisible Punishment: An Instrument of Social Exclusion, in InVisible Punishment: THE COLlateral CONSEQuenCES OF MASS IMPRISONMENT 15, $22-23$ (Marc Mauer \& Meda Chesney-Lind eds., 2002); see also Christopher Mele \& Teresa A. Miller, Collateral Civil Penalties as Techniques of Social Policy, in CIVIL PenAlties, Social Consequences 9, 21 (Christopher Mele \& Teresa A. Miller eds., 2005) (discussing impact of civil penalties).

44. Nora V. Demleitner, Preventing Internal Exile: The Need for Restrictions on Collateral Sentencing Consequences, 11 STAN. L. \& POL’Y REV. 153, 160 (1999).

45. Id.

46. H.R. REP. NO. 110-140, at 2 (2007), reprinted in 2008 U.S.C.C.A.N. 24, 25.

47. Marlaina Freisthler \& Mark A. Godsey, Going Home to Stay: A Review of Collateral Consequences of Conviction, Post-Incarceration Employment, and Recidivism in Ohio, 36 U. TOL. L. REV. 525, 525-26 (2005).

48. Demleitner, supra note 44, at 156.

49. Freisthler \& Godsey, supra note 47, at 531-32.

50. Bruce Western \& Christopher Wildeman, Punishment, Inequality, and the Future of Mass 
In some cases, employment and occupational licensing restrictions are necessary to protect the public. In the context of employment, the most obvious example is the sex-offender pedophile prohibited from driving an elementary school bus. In such a case, an employment restriction is necessary to prevent contact between the offender and children. More importantly there is a reasonable relationship between the underlying criminal conduct, pedophilia, and the occupational duties, including daily interaction with young children. In such a case, an employment prohibition makes sense. However, most offenders are not pedophile sex offenders and in most cases collateral consequences do less to protect the public and more to interject a sense of frustration and hopelessness in the ex-offender, particularly in instances where there is either no nexus or a minimal connection between the disqualifying conviction and the desired employment.

Lack of employment is a primary factor in criminal recidivism and the most severe post-conviction penalty. ${ }^{51}$ "Many ex-offenders released from prison face this obstacle head-on and are repeatedly rejected, denied, and virtually excluded from the qualified applicant pool based solely on their previous conviction." ${ }^{\text {} 52}$ Numerous studies have reported a positive correlation between employment and recidivism. ${ }^{53}$ These are discussed in more detail in the subsequent subsection.

In general, new releasees face high levels of unemployment as well as below-average wages. $^{54}$ On average, "incarceration reduced subsequent wages by $11 \%$, cut annual employment by nine weeks and reduced yearly earnings by $40 \% . " 55$ When years of work experience are statistically controlled, the results change very little. ${ }^{56}$ The implication is

Incarceration, 57 U. KAN. L. REV. 851, 852 (2009).

51. Margaret Colgate Love, Starting Over with a Clean Slate: In Praise of a Forgotten Section of the Model Penal Code, 30 Fordham URB. L.J. 1705, 1719 (2003).

52. Lahny R. Silva, Clean Slate: Expanding Expungements and Pardons for Non-Violent Federal Offenders, 79 U. CIN. L. REV. 155, 165 (2010).

53. Miles D. Harer, Office of Research \& Evaluation, Fed. Bureau of Prisons,

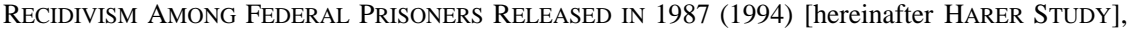
http://www.bop.gov/news/research_projects/published_reports/recidivism/oreprrecid87.pdf; Christopher Uggen, Work as a Turning Point in the Life Course of Criminals: A Duration Model of Age, Employment, and Recidivism, 67 AM. SoCIO. REV. 529 (2000).

54. Bruce Western \& Becky Petit, The Pew Charitable Trusts, Collateral Costs: INCARCERATION'S EFFECT ON ECONOMIC MOBILITY 11 (2010), http://www.pewtrusts.org/uploaded Files/wwwpewtrustsorg/Reports/Economic_Mobility/Collateral\%20Costs\%20FINAL.pdf?n=5996.

55. Id.

56. Id. 
that the economic consequences result from conviction and incarceration rather than "work experience lost while imprisoned." 57 With this, the first order of business is to explore proactive measures connecting releasees with employment. ${ }^{58}$

This section of the Article seeks to explore the various facets of employment consequences of conviction. It begins by surveying a number of empirical studies that demonstrate a link between employment and a decline in criminal recidivism. Section B examines statutory disqualifications triggered by a felony conviction while section $\mathrm{C}$ looks at employers' unwillingness to hire individuals with a felony conviction. Section D discusses the racial implications of disqualifying employment policies. Finally, this part of the Article looks to current government responses to the employment consequences of conviction.

\section{A. Employment and Recidivism}

Numerous recidivism studies have been conducted in recent years. For example, the Bureau of Justice Statistics report of 2002 and the 2011 Pew Center study provided scholars, advocates, and policymakers with valuable insight into the cross-national rate of recidivism. ${ }^{59}$ However, these studies primarily focused on reporting convictions, types of rearrest and reconviction, as well as how previous sentences served as predictors for future criminal behavior. ${ }^{60}$ These factors fail to account for how outside socioeconomic factors such as employment, education, and civic participation influence the rate of recidivism.

In contrast, the last formal study conducted by the Bureau of Prisons, known as the Harer Study, published in 1994, did. ${ }^{61}$ According to the Harer Study, post-release employment is a determinative factor in the successful reintegration of ex-offenders. The majority of incarcerating and recidivating crimes consist of drug trafficking, theft, and larceny, which suggests that many offenses are committed with an economic objective. $^{62}$ In the Harer Study, ex-offenders, who arranged for post-

57. Id

58. Id. at 22 .

59. Patrick A. Langan \& David J. Levin, U.S. Dep't of Justice, Bureau of Justice StATISTICS, SPECIAL REPORT: RECIDIVISM OF PRISONERS RELEASED IN 1994 (2002), http://bjs.ojp. usdoj.gov/content/pub/pdf/rpr94.pdf; PEW CTR., STATE OF RECIDIVISM, supra note 40.

60. See LANGAN \& LeVin, supra note 59; PeW CTR., StATE OF ReCidivisM, supra note 40.

61. HARER STUDY, supra note 53.

62. Id. at 52; see also LANGAN \& LEVIN, supra note 59, at 8 (finding similar results among those with the highest re-arrest rates who were originally incarcerated for committing economic 
release employment, had a recidivism rate of $27.6 \%$ compared to $53.9 \%$ of those without employment. ${ }^{63}$ Therefore, post-release employment appears to cut the recidivism rate by close to half. ${ }^{64}$

Sociologist Christopher Uggen's recent study supports the Harer Study findings. Using older data from the National Supported Work Demonstration Project, Uggen analyzed the work effect on the rate of recidivism. ${ }^{65}$ He reported a $24 \%$ reduction in recidivism for participants in the work program aged twenty-six and older. ${ }^{66}$ This is quite significant as it suggests that employment is an important turning point in the "life course" of offenders over twenty-six years old. ${ }^{67}$

Other studies, reports, and programs demonstrate similar findings. One study, conducted by Stephen Tripodi at Florida State University reported that recidivists who found work when released from prison decreased their chances of recidivism by $68.5 \% .{ }^{68}$ Recidivists with employment averaged 31.4 months before re-incarceration while recidivists who failed to obtain employment averaged 17.3 months before re-incarceration. ${ }^{69}$ The Newark Prisoner Reentry Initiative, a federal Department of Labor funded program aimed at securing employment and vocational training for releasees, boasts a less than $10 \%$ reduction in participants' rate of recidivism after one year. ${ }^{70}$

Also significant is the Harer Study's finding that those offenders released to a halfway house prior to being released to the community were more successful than those directly released. This is because halfway houses increase the likelihood of obtaining post-release employment. $^{71}$ Of the 614 people in the sample who went to halfway houses, $68.1 \%$ obtained employment compared to $22 \%$ of those released directly into the community. ${ }^{72}$ There is, therefore, strong evidence that

\footnotetext{
crimes, with an exception to that pattern being drug traffickers with an average re-arrest rate).

63. HARER STUDY, supra note 53, at $4-5$.

64. Id.

65. Uggen, supra note 53, at 532-33.

66. Id. at 534 .

67. Id. at 542

68. Poster, Stephen J. Tripodi, Fla. State Univ., Coll. of Social Work, http://www.research. fsu.edu/crc/FYAP/posters/Tripodi_FYAP_Poster_Final.pdf (last visited Oct. 9, 2012).

69. Id.

70. Corey Booker, Let's Break the Cycle of Re-Arrest and Re-Imprisonment, N.J. VoICES GUEST BLOG (Jan. 3, 2010, 5:55 AM), http://blog.nj.com/njv_guest_blog/2010/01/lets_break_the_ cycle_of_re-arr.html.

71. HARER STUDY, supra note 53, at 63-66.

72. Id. at $3-4$.
} 
employment is critical to the success of a new releasee. ${ }^{73}$ Education and family support are also key factors in a smooth transition from prison to the community. ${ }^{74}$

\section{B. Statutory Disqualifications}

Once out of prison, ex-offenders have fewer employment opportunities and experience a decreased lifetime earning potential. ${ }^{75}$ The "wage penalty" of imprisonment is estimated somewhere between $10 \%$ and $20 \%{ }^{76}$ This is attributed not only to the lack of skills and work experience that characterize the typical ex-offender, but also the stigmatization and statutory employment restrictions facing exoffenders. $^{77}$

As evidence of its commitment to the War on Drugs and the "tough on crime" stance of the 1980s, the federal government and several states implemented a number of occupational restrictions affecting exoffenders. $^{78}$ These restrictions have assumed the form of blanket

73. Id. at 63-64; see also CHRISTY Visher ET AL., URBAN INST. JUSTICE POL’y CTR.,

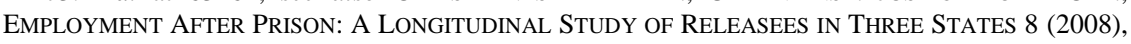
http://urban.org/UploadedPDF/411778_employment_after_prison.pdf.

74. Education also plays an important role in success. The Harer Study demonstrated that recidivism is inversely related to education level. HARER STUDY, supra note 53, at 13 . Those offenders entering prison with an education of eighth grade or less who participated in Adult Basic Education and GED courses had a lower recidivism rate than those who opted out. Id. The same is true of those entering prison with some high school education and participating in Adult Continuing Education, Post-Secondary Education, and Adult Basic Education. Id. A more recent study published in 2003 found similar results, with those offenders who participated in educational programming having a statistically significant lower rate of recidivism overall. STEPHEN J. STEURER

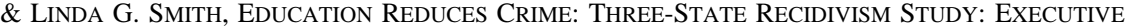
SUMMARY 12 (2003), http://www.ceanational.org/PDFs/EdReducesCrime.pdf.

Family and spousal support is just as determinative as education. The Harer Study reported that those releasees living with a spouse post-release recidivated at a rate of $20 \%$, while those with other living arrangements recidivated at a rate of 47.9\%. HARER STUDY, supra note 53, at 5-6. Moreover, recent research suggests that tangible and emotional familial support and spending time with children are associated with lower rates of recidivism. Rebecca L. Naser \& Nancy G. La Vigne, Family Support in the Prisoner Reentry Process: Expectations and Realities, 43 J. OFFENDER REHAB. 93, 94-95 (2008). Family tends to be the primary source of socioeconomic stability for newly released offenders.

75. Jeremy Travis et al., URBan InSt. Justice Pol'y Ctr., From Prison To Home: The DIMENSIONS AND CONSEQUENCES OF PRISONER REENTRY 31-34 (2001), http://www.urban.org/ UploadedPDF/from_prison_to_home.pdf.

76. Id. at 32

77. Travis, supra note 43 , at 22.

78. See Deborah N. Archer \& Kele S. Williams, Making America "The Land of Second Chances": Restoring Socioeconomic Rights for Ex-Offenders, 30 N.Y.U. REV. L. \& Soc. CHANGE 527, 532-39 (2006) (discussing state employment restrictions); Pinard \& Thompson, supra note 43, 
prohibitions based on an individual's status as a convicted felon. ${ }^{79}$ For example, the state code in Ohio includes 404 statutory collateral consequences. $^{80}$ Of these 404 sanctions, 291 of them are employment related. ${ }^{81}$ Many other states have similar sanctions embedded in their state codes. A recent study conducted by the American Bar Association's (ABA's) Criminal Justice Section catalogued over 38,000 statutes nationwide imposing collateral consequences on individuals. ${ }^{82}$ Of this number, $65 \%$ were employment consequences. ${ }^{83}$

Licensing restrictions result in the loss of new employment and act as a bar on reemployment in the occupation the offender was employed in prior to conviction. ${ }^{84}$ Federal law provides for the suspension and revocation of numerous licenses including commercial motor vehicle operator licenses, ${ }^{85}$ pilots' licenses (called airmen certificates), ${ }^{86}$ hazardous materials equipment licenses (from local trash collectors to interstate trucking companies carrying nuclear waste), ${ }^{87}$ broadcasting licenses, ${ }^{88}$ and port workers' transportation worker identification credential. $^{89}$ This list is by no means exhaustive. States restrict occupational licenses as well by denying or revoking certain types of licenses based strictly on a felony criminal conviction. For example, North Carolina $^{90}$ and New Hampshire ${ }^{91}$ deny, suspend, or revoke barber licenses based on felony convictions while Wisconsin denies security guard licensing. ${ }^{92}$

at 596 (stating in the 1980s a number of states restricted employment opportunities for ex-offenders to show they were tough on crime).

79. Pinard \& Thompson, supra note 43 , at 596.

80. Kimberly R. Mossoney \& Cara A. Roecker, Ohio Collateral Consequences Project: Executive Summary, 36 U. TOL. L. REV. 611, 615 (2005).

81. Id.

82. Letter from Eric Holder, Attorney Gen. of the U.S., to William H. Sorrell, Attorney Gen. of Vt. (April 18, 2011), http://onlawyering.com/wp-content/uploads/2011/05/VT-Attorney-GeneralSorrell.0001-1.pdf.

83. Gowen, supra note 34 , at 2.

84. See Anthony C. Thompson, Navigating the Hidden Obstacles to Ex-Offender Reentry, 45 B.C. L. REV. 255, 282 (2004).

85. 49 U.S.C. § 31310 (2006), amended by Pub. L. No. 112-141, 126 Stat. 405 (West 2012).

86. Id. § 44710; 14 C.F.R. § 61.15 (2010).

87. 49 U.S.C. $\S 5103 a$.

88. 47 C.F.R. $\S 73.4280$.

89. 46 U.S.C. § 70105; 49 C.F.R. §§ 1515.7, 1572.103.

90. N.C. GEN. STAT. ANN. § 86A-18(1) (West 2012).

91. N.H. REV. STAT. ANN. § 313-A:22, II(b) (West 2005).

92. Wis. STAT. ANN. § 440.26(2)(c)2 (West 2012). 
Other federal and state license restrictions are put forth as necessary "to foster high professional standards," while limitations on employment opportunities are said to guarantee that those hired have "good moral character." "93 Suspensions and revocations placed on the licenses of commodity dealers, ${ }^{94}$ customs brokers, ${ }^{95}$ and SEC registrants (brokers and dealers) ${ }^{96}$ are examples where "good moral character" comes into play. All of the above statutes and regulations require criminal background checks and make a conviction a basis for denial. Surprisingly, an ex-offender has a better chance of becoming an attorney than a security guard in Wisconsin or barber in North Carolina. Only five states prohibit felons from practicing law, ${ }^{97}$ while felons are barred from over 800 occupations nationwide. ${ }^{98}$ Collectively, statutory restrictions contribute to an ex-offender unemployment rate of at least $60 \%$ one year after release. ${ }^{99}$

\section{Unwillingness to Hire}

One of the most common problems associated with access-to-work issues is the unwillingness of employers to hire an individual with a criminal record. A number of empirical studies conducted over the past fifteen years demonstrate that approximately $60 \%$ of employers "probably or definitely would not" even consider hiring an individual with a criminal history. ${ }^{100}$ Employers are more reluctant to hire ex-

93. Demleitner, supra note 44, at 156 (quoting Note, Civil Disabilities of Felons, 53 VA. L. Rev. 403, 406 (1967); Neil P. Cohen \& Dean Hill Riukin, Civil Disabilities: The Forgotten Punishment, 35 FED. PROBATION 19, 21 (1971)) (internal quotation marks omitted).

94. 7 U.S.C. § $12 \mathrm{a}(2)$.

95. 19 U.S.C. § $1641(\mathrm{~d})$.

96. 15 U.S.C. 780.

97. Paul Davies, The High Bar for Redemption, WALL ST. J., Mar. 8, 2007, at A1 (reporting that "Indiana, Mississippi, Missouri, Oregon, and Texas prohibit felons from practicing law").

98. Shawn D. Bushway \& Gary Sweeten, Abolish Lifetime Bans for Ex-Felons, 6 CRIMINOLOGY \& PuBlic POL’y 697, 698 (2007).

99. Joan Petersilia, When Prisoners Return to the Community: Political, Economic, and Social Consequences, SENTENCING \& CORRECTIONS, Nov. 2000, at 3, https://www.ncjrs.gov/pdffiles1/nij/ 184253.pdf.

100. Devah Pager \& Bruce Western, InVestigating Prisoner Reentry: The IMPact of Conviction Status ON the EMPloyment PRospects of Young Men 20 (2009), http://www.ncjrs.gov/pdffiles1/nij/grants/228584.pdf (the study was conducted in New York City); Devah Pager \& Lincoln Quillian, Walking the Talk? What Employers Say Versus What They Do, 70 AM. Soc. REV. 355, 363 (2005); see also Harry J. Holzer et al., Will Employers Hire Ex-Offenders? Employer Preferences, Background Checks and Their Determinants, in IMPRISONING AMERICA: THE SOCIAL EFFECTS OF MASS INCARCERATION 205 (Mary Patillo et al. eds., 2001) (surveying employers from 1993-1994 in four cities: Boston, Atlanta, Detroit, and Los Angeles, finding 
offenders than any other commonly stigmatized groups including the disabled, welfare recipients, or applicants with gaps in employment history. ${ }^{101}$ The underlying concerns of this marginalization from the applicant pool include fears of physical safety, theft, and the desire to avoid interaction with probation officers. ${ }^{102}$ One study published in 2009 uncovered that the majority of employers are more concerned about behavioral problems than negligent hiring liability. ${ }^{103}$ Tax incentives and federal bonding-government provided incentives for the hiring of exoffenders-are seriously underutilized reintegrative tools. ${ }^{104}$

\section{Racial Implications}

Princeton Professor and sociologist Devah Pager conducted a study in Milwaukee, Wisconsin demonstrating how a criminal conviction works against black men more harshly than their white counterparts. ${ }^{105}$ Pager's study clearly shows that criminal convictions have a devastating effect on the employment prospects of young black males with criminal convictions in America.

The study was an employment audit conducted with four male testers: two blacks and two whites. ${ }^{106}$ The testers were paired by race; the two black testers formed one team and the two white testers formed the second team. ${ }^{107}$ Within each team, one auditor was randomly assigned a "criminal record" for the first week; the pair rotated the exoffender role for each successive week of employment searches, such that each tester served in the criminal record condition for an equal number of cases. ${ }^{108}$ "[T] conviction (possession with intent to distribute cocaine) and eighteen

exclusion rates of $60 \%)$.

101. Harry J. Holzer et al., Perceived Criminality, Criminal Background Checks, and the Racial Hiring Practices of Employers, 49 J. L. \& ECON. 451, 453 (2006).

102. PAGER \& WESTERN, supra note 100, at 23-25.

103. Id. at 28.

104. See id. at 29-30 ("Though only a small minority of employers ... use tax credits and federal bonding, these incentives do appear to increase employers' willingness to continue hiring exoffenders in the future.”).

105. Devah Pager, Double Jeopardy: Race, Crime, and Getting a Job, 2005 WIS. L. REv. 617, 641 (2005).

106. Id. at 631 .

107. Id.

108. Id. 
months of served prison time.”"109 The testers applied for real job openings in entry-level positions to see whether employers responded differently to applications on the basis of selected characteristics. ${ }^{110}$ The results of the study demonstrated that a criminal record reduced the likelihood of a callback by $50 \% .{ }^{111}$ The callback rate was $34 \%$ for whites with no criminal record, $17 \%$ for whites with a criminal record, $14 \%$ for blacks without a criminal record, and 5\% for blacks with a criminal record. ${ }^{112}$

\section{E. Government Responses}

This "employment penalty" has developed into a major socioeconomic problem for entire communities. The Equal Employment Opportunity Commission (EEOC) is adamant about requiring a connection between the disqualifying conviction and the employment duties, thus ensuring fairness and preventing discrimination. ${ }^{113}$ Only a handful of states, however, currently require any type of relationship test for the nature of the underlying conviction and occupational duties. ${ }^{114}$ One of the problems of challenging employment and occupational disqualification is that ex-offenders as a political block lack the political capital and cohesiveness necessary to facilitate interest by state and federal legislators. Moreover, there is a notion of extreme political risk associated with the advancement of interests of felons and convicts. It is considered a "soft on crime" approach, ${ }^{115}$ particularly if the basis for reform is fairness as opposed to taxpayer savings and reduced government expenditures.

\footnotetext{
109. Id. at 633 .

110. Id. at 629 .

111. Id. at 641 .

112. Id. at 641-43.

113. U.S. EQUAL EMP'T OPPORTUNITY COMM'N, EEOC COMPLIANCE MANUAL 15-29-15-30 (2006), http://www.eeoc.gov/policy/docs/race-color.pdf; U.S. EQUAL EMP'T OPPORTUNITY COMM’N, TITLE VII: USE OF CONVICTION RECORDS IN HIRING (2008), available at http://www.eeoc. gov/eeoc/foia/letters/2008/titlevii_use_conviction_hiring.html.

114. See Legal Action Ctr., Overview of State LaWs that Ban Discrimination by EMPLOYERS, http://www.lac.org/toolkits/standards/Fourteen_State_Laws.pdf (last visited Nov. 1, 2012) (outlining fourteen states that have laws prohibiting employment discrimination of exoffenders).

115. See Adam M. Gershowitz, An Informational Approach to the Mass Imprisonment Problem, 40 ARIZ. ST. L.J. 47, 78 (2008) (discussing the challenge to prison reform in the context of prison overcrowding).
} 
Social organizations and advocacy groups across the country have been working with municipal and state legislatures to "Ban the Box" on employment applications for work in public-sector positions. ${ }^{116}$ "Ban the Box" is an initiative that encourages employers to abandon the criminalconviction question on employment applications. ${ }^{117}$ An employer should ask a prospective employee the question only after choosing her for a second interview. Major cities, such as Boston and Chicago, have enacted rules requiring city employers to review an applicant's qualifications prior to conducting a background check. ${ }^{118}$ Entire states, such as Illinois and Kansas, are following suit with similar legislation. ${ }^{119}$

Mayors across the country have begun to invest in reentry initiatives that aim to put ex-offenders back to work. ${ }^{120}$ In New York, Mayor Bloomberg has led the reentry effort by forming private sector intermediaries to place probationers in jobs that pay a living wage. ${ }^{121}$ Chicago engages in something similar except there job placement is open to all ex-offenders. ${ }^{122}$ Corey Booker, Mayor of Newark, has instituted an aggressive work-first program funded by the Department of Labor and blessed with broad bipartisan support. ${ }^{123}$ Additionally, Booker persuaded 300 lawyers to donate their services to ex-offenders facing legal obstacles to employment, offered tax breaks to companies that hire exoffenders, and has decided to sell city land at a discount price to developers willing to hire ex-offenders on their construction sites. ${ }^{124}$ Entire states have also joined the reintegrative employment efforts. In 2003, Michigan launched the Michigan Prisoner Reentry Initiative (MPRI) and expanded it statewide in $2008{ }^{125}$ Prior to parole or release, offenders are transferred to a reentry facility where a transition plan is

116. See Ban the Box, ALL OF Us OR NONE, http://www.allofusornone.org/campaigns/ban-thebox (last visited Oct. 12, 2012).

117. Id.

118. Nat'l Emp'T Law Project, Major U.S. Cities and Counties Adopt HiRing Policies TO REMOVE UNFAIR BARRIERS TO EMPLOYMENT OF PEOPLE WITH CRIMINAL RECORDS 2-13 (2010), http://www.nelp.org/page/-/SCLP/2010/PromisingLocalHireReentryPolicies.pdf?nocdn=1.

119. See H.R.J. Res. 107, 94th Gen. Assemb., Reg. Sess. (Ill. 2006); KAn. StAT. AnN. § $22-$ 4710 (2008).

120. Kimberly Hendrickson, Reentry Programs for Ex-Prisoners Show Promise, EXAMINER (Apr. 27, 2009), http://www.washingtonexaminer.com/reentr-programs-for-ex-prisoners-show-prom ise/article/37525\#.uotw-1Q1e1s.

121. Id.

122. Id.

123. Id

124. Andrew Jacobs, Seeking the Key to Employment for Ex-Cons, N.Y. TIMES, Apr. 27, 2008, at A31.

125. PeW Ctr., StATE OF ReCidivism, supra note 40, at 21. 
created and implemented ensuring employment opportunity and housing placement upon release. ${ }^{126}$

A number of states have expungement or sealing mechanisms, judicial petitions for expungement, deferred prosecution arrangements, and alternative sanctions for law breakers. ${ }^{127}$ These procedures allow a criminal defendant to deny a conviction in the case of expungement and sealing or avoid a conviction altogether in the instance of a deferred prosecution. A few states offer "certificates of rehabilitation" that may restore some or all of the legal rights lost upon conviction. ${ }^{128}$ Also, a few states permit the presumption of rehabilitation after the passage of time. $^{129}$

Not all states are developing employment strategies for their exoffending population, and even the states that are still have state codes replete with employment restrictions and automatic occupational licensing disqualifications based solely on conviction. Any legislative conversation must begin with repealing or modifying such statutes to facilitate successful reentry. If legislatures fail to take the initiative, then courts must step in to signal the need for serious constitutional review of such laws.

Employment and occupational opportunities for ex-offenders are important not only for the individual but also for the health of our nation both socially and economically. Out-of-work ex-offenders do not make for a safer community. Instead, the unemployment rate of felons contributes to high criminal recidivism and increased corrections expenditures, paid for with taxpayer dollars.

Occupational licenses provide a means through which ex-offenders may avoid employer biases and earn a legitimate income. While some occupational licenses may be necessary to genuinely protect the public (as with the pedophile bus driver example), many times such restrictions have no real rational relationship either to public safety or the underlying occupational duties.

126. Id

127. April Fazier \& Margaret Love, Certificates of Rehabilitation and Other Forms of Relief from the Collateral Consequences of Conviction: A Survey of State Laws, in ABA COMM'N ON EFFECTIVE CRIMinal SANCTIONS, SECOND CHANCES IN THE CRIMINAL JUSTICE SySTEM: ALTERNATIVES TO INCARCERATION AND REENTRY STRATEGIES 50, 50 (2007), http://www.pardon law.com/materials/rev_2ndchance(3).pdf.

128. Id.

129. Id. at 52-53 (finding Arkansas, Minnesota, Montana, New Mexico, and North Dakota all presume rehabilitation with the passage of time). 


\section{Due Process \& CuRRENT Constitutional ChALLENGES}

\section{A. The Right to Work: A “very important 'liberty' interest”}

In McDonald v. Chicago, Justice Stevens, author of BMW v. Gore $e^{130}$ and Padilla $v$ Kentucky, ${ }^{131}$ discussed below, reminded the Court that substantive due process is a matter of individual liberty. ${ }^{132}$ In a stern dissent, Justice Stevens discussed the liberty clause as a constitutional " "promise' that a measure of dignity and self-rule will be afforded [to] all persons."133 Recognizing that "process" implies strict procedural analysis, Justice Stevens asserted that substance and process are intertwined, thus permitting the constitutional interpretation of due process as giving substance to the word "liberty" as it relates to "due process." 134 Furthermore, substantive due process analysis, for Justice Stevens, is a forward-looking methodology. ${ }^{135}$ Citing Lawrence v. Texas and Michael H. v. Gerald D., Justice Stevens understood the analysis to consider the sociopolitical landscape of a modern society. ${ }^{136}$ Although occupational freedom or a "right to work" has never been recognized by the Court as a fundamental right, it has deep roots in the American conception of "ordered liberty," and in today's society individuals are adjudged according to their occupation. Most importantly, Justice Stevens found it to be the Court's responsibility to safeguard individual liberty as opposed to leaving it to "majoritarian political processes.",137 He considered it "judicial abdication" to grant substantial legislative deference on the issue of the liberty guarantee in the Due Process Clause. ${ }^{138}$ It is important to understand this conception as applicable not only in some contexts but in all questions that the Supreme Court faces.

In the 1798 Supreme Court case Calder v. Bull, ${ }^{139}$ Justice Samuel Chase pronounced a set of laws not to be categorically entrusted to legislative authority:

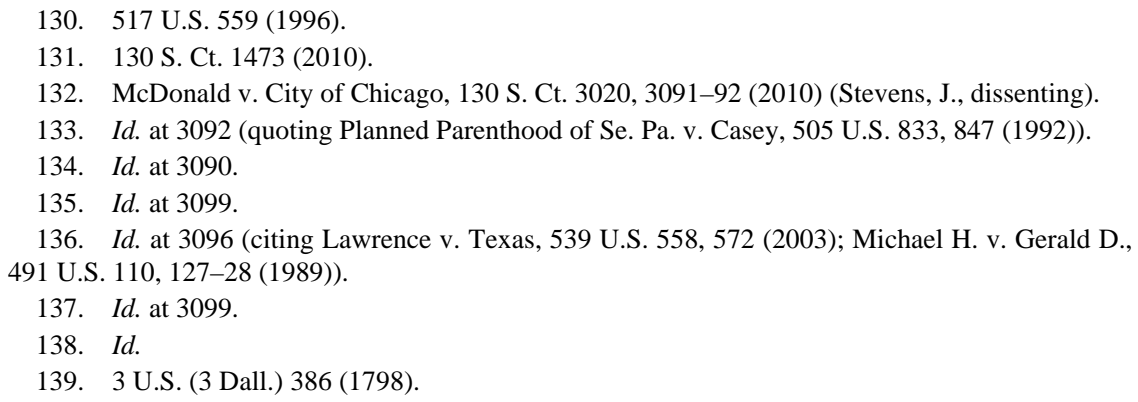


A law that ... impairs[] the lawful private contracts of citizens; a law that makes a man a Judge in his own cause; or a law that takes property from []A and gives it to B: It is against all reason and justice, for a people to entrust a Legislature with SUCH [sic] powers; and, therefore, it cannot be presumed that they have done it.

The Court has put forth a number of constitutionally protected timehonored rights including "the right of the individual to contract, to engage in any of the common occupations of life, to acquire useful knowledge... and generally to enjoy those privileges long recognized ... as essential to the orderly pursuit of happiness by free men."141 It has also asserted that "ineligibility for employment in a major sector of the economy [] is of sufficient significance to be characterized as a deprivation of an interest in liberty."142 When the opportunity to work is at risk of being foreclosed, the government is prevented from favoring some citizens over others. ${ }^{143}$ The state is prohibited from excluding persons from any occupation in a manner that contravenes due process of law. ${ }^{144}$ With this, due process is used as a vehicle guaranteeing fairness and protection against unreasonable and capricious government action. ${ }^{145}$ When evaluating the restriction of employment opportunities, the Court has emphasized that a standard less

\footnotetext{
140. Id. at 388 .

141. Meyer v. Nebraska, 262 U.S. 390, 399 (1923).

142. Hampton v. Mow Sun Wong, 426 U.S. 88, 102 (1976); see also Bd. of Regents of State Colls. v. Roth, 408 U.S. 564, 588-89 (1972) (Marshall, J., dissenting) (“[I]t is also liberty-liberty to work - which is the 'very essence of the personal freedom and opportunity' secured by the Fourteenth Amendment.”); Prudential Ins. Co. of Am. v. Cheek, 259 U.S. 530, 536 (1922) (“That freedom in the making of contracts of personal employment, by which labor and other services are exchanged for money or other forms of property, is an elementary part of the rights of personal liberty and private property, not to be struck down directly or arbitrarily interfered with ...."); Traux v. Raich, 239 U.S. 33, 41 (1915) (“[T] he right to work for a living in the common occupations of the community is of the very essence of the personal freedom and opportunity that it was the purpose of the Amendment to secure.”); Dent v. West Virginia, 129 U.S. 114, 121 (1889) (“It is undoubtedly the right of every citizen of the United States to follow any lawful calling, business, or profession he may choose, subject only to such restrictions as are imposed upon all persons of like age, sex, and condition. This right may in many respects be considered as a distinguishing feature of our republican institutions.”). But see De Veau v. Braisted, 363 U.S. 144, 157 (1960) (holding that New York legislation barring collection from pier superintendents, longshoremen, and hiring agents of dues on behalf of a union where any of the officers or agents has a felony conviction did not violate the Due Process Clause of the Fourteenth Amendment).

143. Roth, 408 U.S. at $588-89$.

144. Willner v. Comm. on Character \& Fitness, 373 U.S. 96, 102 (1963) (citing Schware v. Bd. of Bar Exam'rs, 353 U.S. 232, 238-39 (1957)).

145. Roth, 408 U.S. at 589; see also Schware, 353 U.S. at 238 (stating that the government is prohibited in its regulation of professional employment from foreclosing an array of opportunities "in a manner ... that contravene[s] ... Due Process.”).
} 
than strict scrutiny applies. ${ }^{146}$ Nevertheless, the government deprivation must comport with due process.

These principles are deeply entrenched in American constitutionalism and reached their pinnacle during the infamous Lochner era in which the Supreme Court invalidated a number of statutes on the premise that such statutes interfered with an individual's freedom of contract, ${ }^{147}$ asserting in one case that " $[\mathrm{t}]$ he right to earn a livelihood and to continue in employment unmolested by efforts to enforce void enactments should similarly be entitled to protection in the absence of adequate remedy."148 The method employed, substantive due process analysis, was soon thereafter repudiated, the death toll ringing with West Coast Hotel Co. v. Parrish in 1938. ${ }^{149}$ With the New Deal and the "Switch in Time That Saved Nine," the Court back peddled on the existence of a "right" to earn a livelihood in NLRB $v$. Jones \& Laughlin Steel Corp. ${ }^{150}$ Instead of looking into the substance of legislative actions regarding occupational freedom and assessing it for fairness, the Court gave almost absolute deference to legislative action. ${ }^{151}$ However, substantive due process analysis may still thrive in one specific instance: to protect a discrete and insular minority. ${ }^{152}$ Whether ex-offenders as a group would qualify as such - a discrete and insular minority-is a question only for the United States Supreme Court.

\section{B. Collateral Consequences in the Supreme Court}

Historically, the treatment of collateral consequences has been inconsistent at best. Judges and lawyers alike are unsure of whether they are criminal or civil, collateral or direct, and whether or not they are significant enough to trigger particular constitutional safeguards. The Supreme Court itself passes down mystifying opinions in its review of collateral consequences. It appears as though the Court itself is puzzled regarding whether these penalties are direct or collateral and whether

\footnotetext{
146. See Dandridge v. Williams, 397 U.S. 471, 485 (1970) (discussing that a state's economic laws merely need a reasonable basis).

147. Adair v. United States, 208 U.S. 161, 176 (1908), overruled in part by Phelps Dodge Corp. v. NLRB, 313 U.S. 177 (1941); Lochner v. New York, 198 U.S. 45, 57-58 (1905), overruled in part by Ferguson v. Skrupa, 372 U.S. 726 (1963).

148. Traux v. Raich, 239 U.S. 33, 38 (1915).

149. 300 U.S. 379, 391 (1937) (recognizing limits to liberty under the Due Process Clause).

150. 301 U.S. 1 (1937).

151. See id. at 43-46.

152. United States v. Carolene Prods. Co., 304 U.S. 144, 152 n.4 (1938).
} 
they are entitled to constitutional review. In fact, the Court has rarely reviewed cases challenging collateral consequences of conviction. However, there have been a few instances where the Court granted certiorari. These cases have led to opinions in the context of voting, sex offender registration, and deportation.

\section{Collateral Consequences Generally}

In 1974, the Court reviewed a constitutional challenge to felon disenfranchisement in Richardson v. Ramirez. ${ }^{153}$ In that case, the Court held that disenfranchisement based on a felony conviction does not violate the Equal Protection Clause of the Fourteenth Amendment. ${ }^{154}$ Justice Rehnquist, writing for the majority, reasoned that the text of the clause explicitly allowed limitations on voting, asserting that the constitutional text itself explicitly calls for disenfranchisement for participation "in rebellion, or other crimes." ${ }^{155}$ This, however, has not foreclosed challenges on other constitutional grounds. ${ }^{156}$

In the 2003 case of Connecticut Department of Safety v. Doe, ${ }^{157}$ the Supreme Court considered the collateral consequence of public disclosure of state sex offender registrations. The Court reversed the Second Circuit's ruling that the respondent was deprived of his liberty interest in his reputation without procedural due process. ${ }^{158}$ Drawing on precedent, the Court asserted that individuals do not possess a liberty interest in reputation alone. ${ }^{159}$ More importantly, the Court signaled that this case had more to do with substantive due process than procedural due process, but because the respondent disavowed the substantive argument, the Court would not consider the issue. ${ }^{160}$ This signifies the

\footnotetext{
153. 418 U.S. 24 (1974).

154. Id. at 54 .

155. Id. at 43 (quoting U.S. CoNST. amend. XIV, § 2, cl. 2) (internal quotation marks omitted).

156. For example, in Farrakhan v. Gregoire, a three judge panel of the Ninth Circuit ruled that Washington's felon disenfranchisement law violated the statutory requirements of $\S 2$ of the Voting Rights Act. 338 F.3d 1009, 1016 (9th Cir. 2003). The court further found that plaintiffs met their summary judgment burden of proving that the discriminatory impact of the disenfranchisement law was attributable to racial discrimination in the Washington criminal justice system. Id. at 1019-20. However, after remand, the case returned to the Ninth Circuit, and on rehearing en banc, the Ninth Circuit reversed its earlier decision and held that the law does not violate $\S 2$ of the Act. 623 F.3d 990, 994 (9th Cir. 2010) (en banc) (per curiam).

157 538 U.S. 1 (2003).

158. Id. at 8 .

159. Id. at 6-7 (citing Paul v. Davis, 424 U.S. 693 (1976)).

160. Id. at 8 .
} 
Court's willingness to review a substantive due process challenge to collateral consequences. ${ }^{161}$

In the most recent case on collateral consequences, Padilla $v$. Kentucky, the Court reversed and remanded a judgment of the Kentucky Supreme Court rejecting the defendant's ineffective assistance of counsel claim when the defendant's lawyer failed to advise him of the immigration consequences of pleading guilty to a drug trafficking offense. ${ }^{162}$ In rejecting the claim, the Kentucky Supreme Court viewed potential deportation as a collateral consequence of conviction and therefore outside the scope of the protections of the Sixth Amendment. ${ }^{163}$ Reversing, Justice Stevens writing for the majority held that Sixth Amendment Strickland requirements necessitate counsel to "inform her client of whether his plea carries a risk of deportation"-a consequence of a felony conviction. ${ }^{164}$ While the opinion refused to categorize deportation as a direct or collateral consequence, it did recognize the confusion over the categorization of direct versus collateral distinction. ${ }^{165}$

\section{Constitutional Challenges to Occupational Licenses}

The Supreme Court has examined challenges to occupational licensing restrictions based on felony conviction in only a few cases. The first case that encountered this issue was Hawker v. New York in 1898. ${ }^{166}$ There, the Court upheld a statute that criminalized the practice of medicine by individuals with a felony conviction. ${ }^{167}$ The defendantdoctor was convicted of performing an abortion in contravention of New York criminal law and was subsequently barred from practicing

161. The Court also reviewed but failed to address the issue of the 2006 Sex Offender Registration and Notification Act (SORNA) as applied to juveniles. United States v. Juvenile Male, 130 S. Ct. 2518 (2010) (per curiam). The United States petitioned for certiorari requesting review of the Ninth Circuit's determination that retroactive application of SORNA to individuals adjudicated delinquent prior to its enactment violated the Ex Post Facto Clause of the Constitution. Id. at 2519. The Court found the issue moot as the respondent had reached the age of majority by the time the case reached the Court. Id. However, the Court did two important things in its per curiam opinion. First, it reiterated the notion that collateral consequences are sufficient to satisfy Article III's injuryin-fact requirement for standing. Id. Second, the Court hinted that a judgment of the Court in this matter could remedy the collateral consequence of a conviction. Id. at 2519-20. Both of these taken together indicate willingness, even if lukewarm, to address issues regarding collateral consequences.

162. 130 S. Ct. $1473,1486-87$ (2010).

163. Id. at 1481.

164. Id. at 1486.

165. Id. at 1482 .

166. 170 U.S. 189 (1898).

167. Id. at 199-200. 
medicine. ${ }^{168}$ Dr. Hawker alleged a violation of the Ex Post Facto Clause of the Constitution. ${ }^{169}$ The Court reasoned that this prohibition was not an additional punishment but was instead a regulation premised on evidence of the unfitness of the offender-the evidence being the fact of conviction. ${ }^{170}$

A little over fifty years later, the Court confronted the issue of occupational licensing restrictions again in Barsky $v$. Board of Regents. ${ }^{171}$ The Court found a New York statute suspending a physician's license upon felony conviction constitutionally permissible. ${ }^{172}$ In that case, the physician-defendant was convicted for failing to comply with a congressional subpoena, and his license was subsequently revoked per the statute. ${ }^{173}$ He argued that the statute under which he was "convicted" was not a "crime," thereby failing to provide a basis for the suspension of his license. ${ }^{174}$ Dr. Barsky argued that the statute permitting the suspension was unconstitutionally vague and therefore a violation of due process. ${ }^{175}$ The Court distinguished the New York statute giving the Board of Regents broad discretion in determining whether to revoke a license from those statutes requiring automatic termination of a license upon felony conviction. ${ }^{176}$ For the Court, the discretionary nature of the statute coupled with New York's interest in public safety was determinative. ${ }^{177}$ The statute was therefore constitutionally reasonable. ${ }^{178}$

In De Veau v. Braisted, the Court upheld a statute that disqualified individuals with felony convictions from holding union offices in specific waterfront occupations. ${ }^{179}$ The appellant alleged due process violations and unconstitutional ex post facto and bill of attainder

\footnotetext{
168. Id. at 192; Miriam J. Aukerman, The Somewhat Suspect Class: Towards A Constitutional Framework For Evaluating Occupational Restrictions Affecting People With Criminal Records, 7 J.L. SOC'Y 18, 28 (2005). For more discussion of the effect of collateral consequences on abortion doctors, see Gabriel J. Chin, Are Collateral Sanctions Premised on Conduct or Conviction?: The Case of Abortion Doctors, 30 FORDHAM URB. L.J. 1685 (2003).

169. Hawker, 170 U.S. at 190-91.

170. Id. at 197.

171. 347 U.S. 442 (1954).

172. Id. at $454-55$.

173. Id. at $444-45$.

174. Id. at 448 .

175. Id.

176. Id. at 452 .

177. Id. at 456 .

178. Id.

179. 363 U.S. 144, 153-54, 160 (1960).
} 
claims. ${ }^{180}$ The Court determined that the exclusion of convicted felons from holding union offices in this context was constitutionally permissible because waterfront commercial enterprises were particularly susceptible to corruption. ${ }^{181}$ The New York state interest in preventing such corruption was justifiable, and the means of preventing such corruption, barring ex-offenders from holding office, was constitutionally permissible. ${ }^{182}$

Outside of the Lochner era, the Supreme Court has not dealt with occupational licensing restrictions with any real consistency. It is clear that the Court will give substantial deference to legislatures and, many times, will find against an ex-offender's interest in occupational freedoms. However, the Court has developed no real framework to evaluate such challenges. Furthermore, reasoning employed in prior case law is no longer applicable in an era when one in four Americans have some type of criminal history. The Supreme Court has not heard an occupational licensing challenge to date. As a result lower courts have been forced to develop jurisprudence in this area by parsing through older Supreme Court precedent and newer circuit court of appeals case law.

\section{Current Constitutional Challenges}

Claims challenging occupational licensing restrictions have been customarily brought under equal protection and due process. ${ }^{183}$ Due process has permitted challenges under procedural due process, substantive due process, and the irrebuttable presumption doctrine. The question becomes whether the classification is arbitrary and whether there is a rational relationship to a legitimate state interest while simultaneously giving substantial deference to legislative action. ${ }^{184}$ Because ex-offenders are not considered a suspect class, equal protection analysis regarding occupational licensing disqualifications is essentially the same. ${ }^{185}$ While it has been argued that ex-offenders ought to be

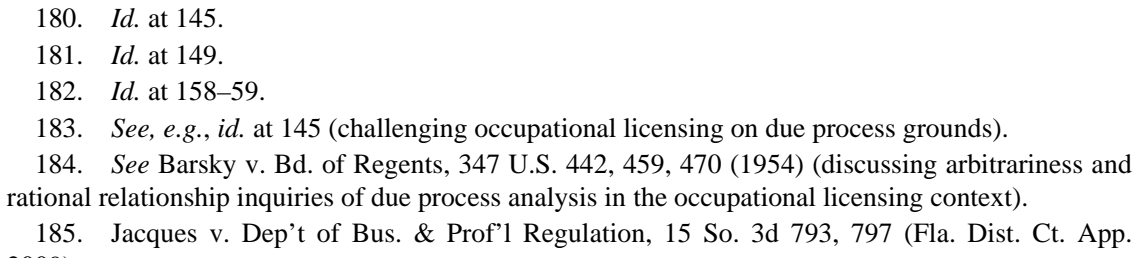


treated as a suspect class, two main obstacles exist. ${ }^{186}$ First, ex-offenders are themselves responsible for their classification by their individual engagement in criminal conduct. ${ }^{187}$ Thus, the "felon" label is preventable. It is also distinguishable from the immutable characteristics of race, sex, and alienage, which are traditionally entitled to a higher degree of constitutional scrutiny. ${ }^{188}$ In addition, the text of the Fourteenth Amendment permits the disenfranchisement of felons upon a finding of participation in "crimes." 189 These obstacles make it difficult for reviewing courts to find constitutionally impermissible discrimination on the basis of felony conviction. Moreover, states have broad authority under their police power to protect the health, safety, and morals of their citizens. ${ }^{190}$ Most state statutes disqualifying ex-offenders from occupational licenses typically do so with "public safety" or "public trust" as the basis for the denial. ${ }^{191}$ In such instances, the state has a weightier interest at stake than the interest of an unprotected class of persons.

Procedural due process claims have also been levied against state occupational licensing restrictions. The Supreme Court has held it is constitutionally impermissible for a state to arbitrarily exclude persons from an occupation. ${ }^{192}$ However, it remains unclear whether an individual who has been denied a professional license is entitled to a hearing if the denial is based on facts that may be adjudicated at a hearing. Some decisions concerning a "property" right in a professional license indicate that no hearing is required unless the individual previously received a license that the state seeks to revoke. ${ }^{193}$ Thus, an individual denied an initial license would have to sue to have the denial

186. Ben Geiger, Comment, The Case for Treating Ex-Offenders as a Suspect Class, 94 CAL. L. REV. 1191, 1191-92 (2006).

187. Id.

188. Id. at 1206.

189. Id. at 1231 (citing Richardson v. Ramirez, 418 U.S. 24 (1974)).

190. DeCanas v. Bica, 424 U.S. 351, 356 (1976).

191. Schanuel v. Anderson, 708 F.2d 316, 319 (7th Cir. 1983) (promoting public trust in a detective agency); Austin v. Ariz. Registrar of Contractors, No. 2 CA-CV 2008-0175, 2009 WL 638106, at *5-7 (Ariz. App. 2009) (mem.) (protecting public from unscrupulous and unqualified contractors); Jacques v. Dep't of Bus. \& Prof'l Regulation, 15 So. 3d 793, 797 (Fla. Dist. Ct. App. 2009) (operating slot machines in a safe and lawful manner); Jurek v. Ohio Motor Vehicle Dealers Bd., 651 N.E.2d 3, 5 (Ohio Ct. App. 1994) (reducing risk of public exposure to unscrupulous business practices).

192. Schware v. Bd. of Bar Exam'rs, 353 U.S. 232, 238-39 (1957).

193. Bd. of Regents of State Colls. v. Roth, 408 U.S. 564, 576-77 (1972) (citing Goldberg v. Kelly, 397 U.S. 254 (1970)). 
reviewed. Furthermore, while notice is an essential component of due process, the traditional meaning of "fair notice," where a person of ordinary intelligence comprehends that her conduct is prohibited and subject to consequences, ${ }^{194}$ allows significant leeway in the way state agencies comport with due process. Questions remain regarding whether a statute that denies ex-felons licenses satisfies the requirement of fair notice.

The irrebuttable presumption doctrine, a hybrid of substantive and procedural due process, appeared to offer the most promising challenge to occupational licensing restrictions. In the early 1970s, the Supreme Court reviewed five cases regarding statutory classifications. ${ }^{195}$ The Court concluded that the state was constitutionally forbidden from establishing an irrebutable presumption where it classified individuals for purposes of allocating a burden or benefit without making a determination of the individual's claim. Therefore, a due process violation occurs when a legislatively important fact is presumed from a separately proven fact under a process or procedure in which the individual involved was denied an opportunity to rebut the presumption. $^{196}$ For example, in Cleveland Board of Education $v$. LaFleur, the Court invalidated employment restrictions on pregnant teachers where no procedure was provided to make individualized determinations on their ability to work during their pregnancies. ${ }^{197}$ While the irrebuttable presumption doctrine does not strictly conform to a procedural due process analysis, it does highlight important due process concerns. When the state distributes burdens or benefits, a fair procedure is necessary. Such challenges met with some success but were otherwise short-lived. ${ }^{198}$ The doctrine was criticized for confusing

194. United States v. Batchelder, 442 U.S. 114, 123 (1979).

195. Cleveland Bd. of Educ. v. LaFleur, 414 U.S. 632, 644 (1974); U.S. Dep’t of Agric. v. Murry, 413 U.S. 508, 514 (1973); Vlandis v. Kline, 412 U.S. 441, 452 (1973); Stanley v. Illinois, 405 U.S. 645 (1972); Bell v. Burson, 402 U.S. 535, 542-43 (1971).

196. Butts v. Nichols, 381 F. Supp. 573, 582 (S.D. Iowa 1974). See generally, Note, The Irrebuttable Presumption Doctrine in the Supreme Court, 87 HARV. L. REV. 1534, 1539-44 (1974) (discussing the Supreme Court's irrebuttable presumption doctrine on certain statutory classifications).

197. 414 U.S. at 644

198. Kindem v. City of Alameda, 502 F. Supp. 1108, 1112 (N.D. Cal. 1980) (finding unconstitutional irrebuttable presumption in violation of due process by state when ten-year-old conviction served as the basis for dismissal); Davis v. Bucher, 451 F. Supp. 791, 800 (E.D. Pa. 1978) (finding city employment excluding former drug users from public employment violative of due process under irrebuttable presumption); Brandt v. Fox, 153 Cal. Rptr. 683, 688-90 (Cal. Ct. App. 1979) (holding due process violation when Attorney General denied real estate license to individual on basis of older drug conviction). 
traditional constitutional analysis under due process and equal protection. ${ }^{199}$ With Connecticut Department of Public Safety v. Doe, the due process irrebuttable presumption doctrine was reasoned away and put to sleep. ${ }^{200}$

Understanding that the customary constitutional protections used to evaluate statutes for fairness are virtually inoperable in the context of individual occupational rights, this Article looks to a different framework that may serve as the mode of analysis. BMW v. Gore and its progeny provide doctrinal underpinnings in the creation of a workable framework.

\section{BMW GUIDEPOSTS AS DOCTRINAL PRINCIPLES}

$B M W v$. Gore established the constitutional framework currently governing substantive due process review of punitive damages awards. Prior to $B M W$, the Court explicitly recognized that the Due Process Clause of the Fourteenth Amendment specifically imposed a substantive limit on punitive damages awards. ${ }^{201}$ However, the Court dealt with such issues largely on a procedural level. ${ }^{202}$ After BMW in 1996, the Court began to look into the sum and substance of such judgments. It was the first case in the Court's history in which it employed a strict application of proportionality review, and it protected a multinational, multibillion dollar corporation: BMW of North America. ${ }^{203}$

\section{A. Fair Notice}

In $B M W$, the Court evaluated the punitive damages award according to two main principles under the Due Process Clause. First, it assessed the judgment with a procedural due process analysis, specifically honing in on whether the corporation received fair notice. ${ }^{204}$ The Court asserted that due process dictates that a person not only receive fair notice of "the conduct that will subject him to punishment, but also of the severity of

\footnotetext{
199. Note, supra note 196, at 1547.

200. Conn. Dep’t of Pub. Safety v. Doe, 538 U.S. 1, 8 (2003).

201. TXO Prod. Corp. v. Alliance Res. Corp., 509 U.S. 443, 455 (1993) (plurality opinion). The Supreme Court held that the $\$ 10$ million punitive damages award did not violate due process. Id. at 451. The compensatory award was $\$ 19,000$. Id.

202. Erwin Chemerinsky, The Constitution and Punishment, 56 StAN. L. REv. 1049, 1055

203. BMW of N. Am. v. Gore, 517 U.S. 559, 585-86 (1996).

204. Id. at 574 .
} (2004). 
the penalty that a State may impose." ${ }^{205}$ Thus, a person must have notice of both the conduct that triggers the penalty as well as the harshness of the penalty. While pointing out that the more stringent constitutional protections afforded to criminal defendants are not applicable to civil cases generally, the Court asserted that basic due process safeguards can be triggered in the context of civil penalties. ${ }^{206}$ The principle developed under $B M W$ established a fair notice test for reviewing civil penalties. Lower courts are to consider (1) whether the person received fair notice that her conduct will subject her to punishment, and (2) whether she received fair notice of the severity of the penalty that a state may impose for that conduct.

\section{B. "Reasonableness" and the BMW Guideposts}

In $B M W$, the Court also evaluated the reasonableness of the punitive damages judgment. The Court fashioned a three-part test to serve as "guideposts" for lower courts when evaluating such awards. These guideposts include evaluating (1) the degree of reprehensibility of the defendant's conduct, ${ }^{207}(2)$ the ratio of punitive damages to the actual and potential harm that the plaintiff and other conceivable victims suffered, ${ }^{208}$ and (3) an inquiry into how punitive damage awards compare with the civil and criminal penalties that had been or could be imposed for comparable misconduct. $^{209}$ These principles form the framework of reasonableness review of civil penalties. The three guideposts, although harshly criticized, are both neutral and general and have the ability to transcend the outcome of these types of cases as well as apply to a different civil penalty context.

\section{Degree of Reprehensibility}

The degree of reprehensibility is an important indicator of reasonableness in this framework. ${ }^{210}$ Within this guidepost lies the wellestablished theoretical principle of proportionality: that a punishment

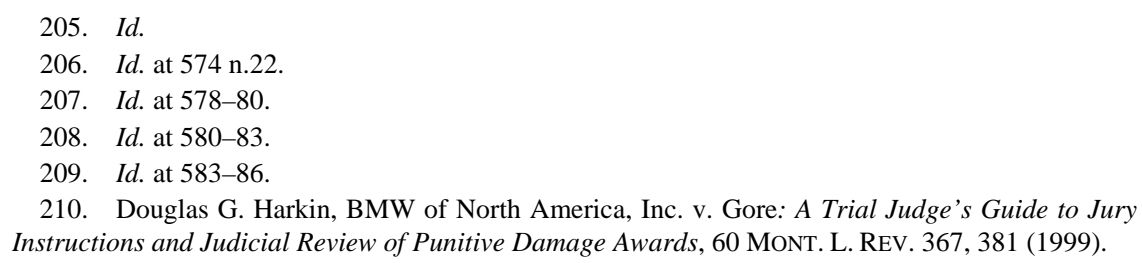


issued should fit the crime committed. ${ }^{211}$ Some acts are more blameworthy than others and should be treated accordingly. In measuring the degree of reprehensibility, the Court relied heavily on common law jurisprudence and criminal law analogies. ${ }^{212}$ To demonstrate how lower courts should evaluate reprehensibility, the Court reiterated certain established principles including that "nonviolent crimes are less serious than crimes marked by violence or the threat of violence" and specific acts such as "trickery and deceit' are 'more reprehensible than negligence.”213 The Court also attempted to articulate aggravating factors to use to assess the degree of reprehensibility, including whether the harm was strictly economic or harmful to the health and safety of individuals, and the financial vulnerability of the plaintiff-victim. ${ }^{214}$ Clearly, the Court was extracting principles from other contexts and using them to analytically strengthen its judgment.

Punitive damages are different than collateral consequences because punitive damages are a creature of tort, contract, and civil law while collateral consequences are the result of criminal conduct and criminal law. However, constitutional jurisprudence in this country has mixed the two areas throughout history. For example, forfeiture is governed by civil law and is a civil process but can be initiated (and often is) as the result of criminal conduct. ${ }^{215}$ In $B M W$, the Court cites numerous criminal cases in support of the ratio it advanced under the second guidepost, including Williams v. New York, ${ }^{216}$ Miller v. Florida, ${ }^{217}$ and Lankford v. Idaho. ${ }^{218}$

\section{Ratio-Proportionality Review}

The second guidepost, the ratio of punitive damages to the actual and potential harm, is the most criticized of the three. It is also the guidepost that has been most modified by subsequent cases. In $B M W$, the Court hesitated to create a bright-line ratio of compensatory damages to

\footnotetext{
211. Id.

212. Id.

213. BMW, 517 U.S. at 576 (quoting Salem v. Helm, 463 U.S. 277, 292-93 (1983); TXO Prod. Corp. v. Alliance Res. Corp., 509 U.S. 443, 462 (1993)) (internal quotation marks omitted).

214. Id.

215. See supra Part II.B (discussing civil forfeiture statutes triggered by past criminal conduct).

216. BMW, 517 U.S. at 573 n.19 (citing Williams v. New York, 337 U.S. 241 (1949)).

217. Id. at 574 n.22 (citing Miller v. Florida, 482 U.S. 423 (1987)).

218. Id. (citing Lankford v. Idaho, 500 U.S. 110 (1991)).
} 
punitive damages. $^{219}$ The Court asserted that a 500:1 ratio "rais[ed] a suspicious judicial eyebrow" and was beyond an appropriate range of acceptable punitive awards. ${ }^{220}$ However, the standard began to evolve with the Court's judgment in State Farm Mutual Automobile Insurance Co. v. Campbell. ${ }^{221}$ In State Farm, the Court found a \$145 million punitive damage award against State Farm for a bad faith failure to settle an insurance claim within policy limits grossly excessive and violative of substantive due process. ${ }^{222}$ The trial court reduced the judgment to \$25 million. $^{223}$ Applying BMW's three guideposts, the Utah Supreme Court reinstated the jury's original punitive damages award. ${ }^{224}$ Granting certiorari, the Supreme Court invalidated the punitive damages award against the insurance giant as excessive under due process. ${ }^{225}$ For the Court, a 145:1 ratio was excessive, whereas $1: 1$ or $4: 1$ would satisfy due process. ${ }^{226}$ Five years later in Exxon Shipping Co. v. Baker, ${ }^{227}$ the Court not only reiterated the principle that excessive punitive damages awards violate due process, but also that a 1:1 compensatory-to-punitive damages ratio is the rule in federal maritime cases. ${ }^{228}$ According to the majority, such a ratio protects against unpredictable and arbitrary awards issued for strictly retributive purposes. ${ }^{229}$ In essence, Exxon stands for the proposition that the ratio between compensatory and punitive damages is constitutional only if they are equal. ${ }^{230}$ This reaches the "outermost limit of the due process guarantee."231

Today it is quite clear that large punitive damage awards with a small compensatory damage counterpart will no longer be constitutionally permissible. The Court not only applied strict

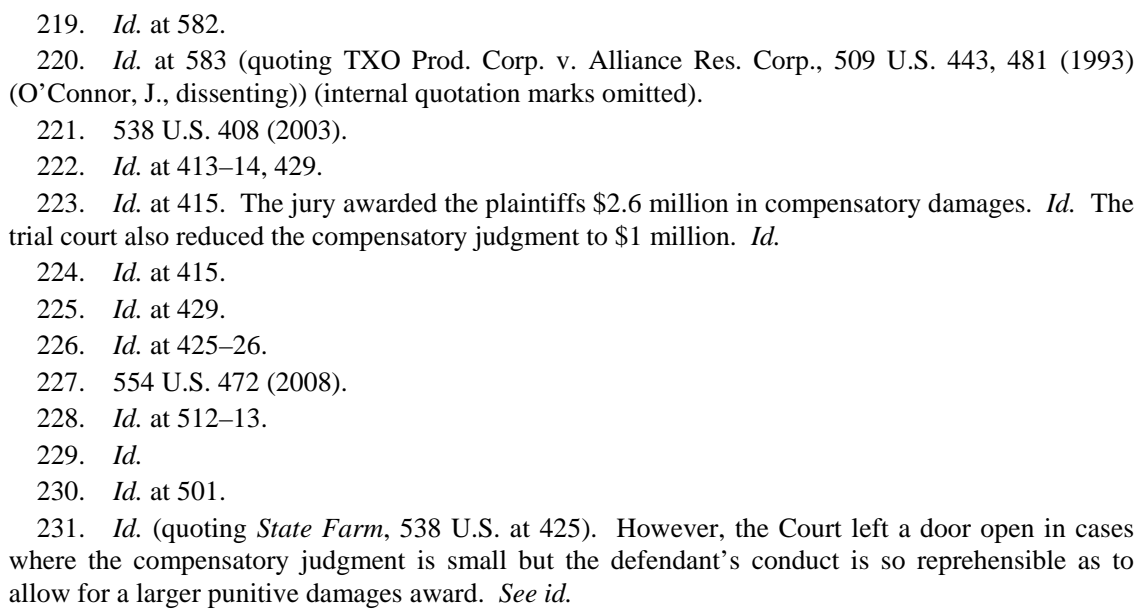


proportionality for the first time, but it also crafted a principle that required strict proportionality review in the constitutional evaluation of civil penalties. Now, civil penalties will be found excessive if the actual and potential harm to plaintiffs were minimal and the civil penalty massive.

\section{Comparative Prong}

The third guidepost assesses sanctions for comparable misconduct. In essence, the Court compares the punitive damages judgment against the criminal or civil sanctions that may have been imposed for similar misconduct in that particular jurisdiction. ${ }^{232}$ Within this guidepost lies substantial legislative deference regarding suitable sanctions for conduct at issue in both the civil and criminal contexts. ${ }^{233}$ In its analysis the Court also compared civil penalties levied against wrongdoers in other jurisdictions. ${ }^{234}$ The statute at issue in $B M W$ was a provision from the Alabama Deceptive Trade Practice Act. ${ }^{235}$ The Court looked at other states' statutes including New York's. ${ }^{236}$ This permits flexibility in evaluating the fairness of a given state's statutory approach on a particular civil penalty.

\section{Summary}

The Court ultimately found that BMW did not have adequate notice that it could be exposed to such a large judgment. ${ }^{237}$ For the Court, the fact that BMW is a "large corporation rather than an impecunious individual" was of no legal consequence. ${ }^{238}$ Nor was the statute's existence of relevant import. Instead, without a substantial history of noncompliance and with the national economic interest favoring tradefriendly statutes, the Alabama judgment was determined excessive and therefore violative of due process. ${ }^{239}$

A number of important matters arise from this new line of case law. First, it appears the Court is resurrecting substantive due process as a

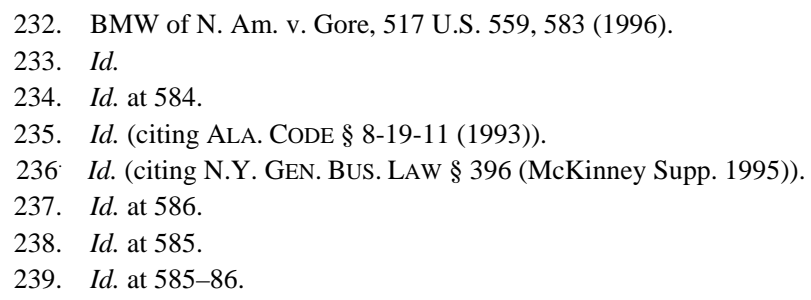


means of analysis for civil penalties. Unequivocally, the court looked into the sum and substance of the statutory schema and the facts surrounding the issue. This is quite different from the legislative deference the Court has traditionally given in due process challenges, especially when evaluating judgments affecting economic freedoms. ${ }^{240}$

Of course, the composition of the Court has changed substantially since $B M W$. Three of the five Justices in the majority left the Court, including Justices Souter, O’Connor, and Stevens, leaving many on the Court in the dissent. ${ }^{241}$ Justice Scalia's dissent primarily rested on the lack of a "principled” decision. ${ }^{242}$ Justice Ginsburg's dissent discussed the Court's vague application of substantive due process as the "raised eyebrow test."243 The most recent punitive damages case, Exxon Shipping Co. v. Baker, produced an even split among the Justices including a concurrence by Justice Scalia agreeing with the application of precedent but disagreeing with the underlying holding. ${ }^{244}$ Because of the uncertainty in the future of this approach with the current composition of the Court, it is important to think of this decision's application in a different civil penalties context in order to adhere to stare decisis.

Finally and most importantly, the Court developed a set of neutral and general principles that can be used to assess the fairness of civil penalties broadly. Although not frequently referenced outside of the context of punitive damages, the Court has referenced the opinion in $B M W$ in one other setting. To date, the Court has applied the principles in the context of criminal sentencing. ${ }^{245}$ Although not directly on point, this demonstrates the potential applicability of the framework. Moreover, the Court utilized much criminal punishment case law to shape its guideposts in $B M W{ }^{246}$ Before applying this framework to

240. Jeffrey M. Shaman, On the 100th Anniversary of Lochner v. New York, 72 TENN. L. REV. 455, 492 (2005); see also supra notes 145-46 and accompanying text.

241. BMW, 517 U.S. at 561.

242. Id. at 598-99 (Scalia, J., dissenting); see also State Farm Mut. Auto. Ins. Co. v. Campbell, 538 U.S. 408, 429 (2003) (Scalia, J., dissenting).

243. BMW, 517 U.S. at 613 (Ginsburg, J., dissenting).

244. 554 U.S. 471, 515 (2008) (Scalia, J., concurring).

245. United States v. Watts, 519 U.S. 148, 152 (1997) (citing BMW for the principle that a sentencing judge may consider all information concerning the defendant's characteristics and offenses).

246. BMW, 517 U.S. at 574 n.22, 575-76 (citing Lankford v. Idaho, 500 U.S. 110 (1991); Miller v. Florida, 482 U.S. 423 (1987); Solem v. Helm, 463 U.S. 211 (1983)). 
occupational licensing restrictions, it is important to note the limitations and critique of these principles.

\section{Critique and Limitations}

The recent punitive damages line of cases has been the subject of extreme criticism. The critique takes two forms: legal and normative. With the more general legal critique, scholars look at the legal effects and implications of the Supreme Court decisions and offer suggestions for reform. The normative critiques, however, compare the protections advanced by the Court for big business and wealthy corporations in the punitive damages setting with the minimal safeguards offered to individuals in the criminal punishment context.

\section{a. General Critique}

The primary general critique rests on the premise that the Court has failed to develop a doctrine that provides actual guidance to lower courts in their assessment of the reasonableness of punitive damages judgments. $^{247}$ The guideposts themselves are described as "contradictory" and "point in no particular direction."248 Creative lower courts can easily distinguish the punitive damages line of cases from whatever case they are deciding. ${ }^{249}$ Scholars base their opinions on the notion that the first two guideposts are inherently subjective and dependent on the norms of the assessor, versus objective factors that are evaluated independently without the assessor's biases and opinions. ${ }^{250}$

An additional critique of the case law is that in this context the Supreme Court has become a conservative activist Court, advancing tort reform through its majority decision. ${ }^{251}$ Instead of deferring to legislative judgment, "the Court has itself chosen to craft a new jurisprudence of excessiveness to achieve” the end it desired. ${ }^{252}$ Simply

247. Keith N. Hylton, Due Process and Punitive Damages: An Economic Approach, 2 CHARLESTON L. REV. 345, 347 (2008).

248. Doug Rendleman, Common Law Punitive Damages: Something for Everyone?, 7 U. ST. THOMAS L.J. 1, 13 (2009).

249. Id.

250. A. Benjamin Spencer, Due Process and Punitive Damages: The Error of Federal Excessiveness Jurisprudence, 79 S. CAL. L. REV. 1085, 1096-98 (2006).

251. See Rendleman, supra note 248, at 13-14 (explaining that in previous cases the conservative Justices were divided on tort reform until Justices Alito and Roberts allied with the majority to find a substantive due process limit in punitive damage judgments).

252. Spencer, supra note 250, at 1090. 
put, the Court distorted and misused prior precedent to support and legitimize a doctrine that it completely made up. ${ }^{253}$

Finally, a criticism is levied against the majority opinion as removing the original purpose behind punitive damages, namely retribution and deterrence, from the equation. If deterrence is achieved by the issuance of punitive damages, it is because of the economic loss suffered as a result of the defendant's wrongdoing. ${ }^{254}$ Multibillion-dollar companies will not be affected by a judgment that does not hurt their pocketbook. Instead, businesses will begin to include punitive damages in their risk assessments across the board. This effectively reduces risk prevention in the corporate environment. Punishment itself requires the establishment of an upper limit by a legislative body thereby reflecting society's judgment of the wrongful conduct and the type of punishment to subject a wrongdoer to. ${ }^{255}$

b. Normative

By limiting punitive damages based on the compensatory award as opposed to using the defendant's resources as a tool in assessing an adequate punishment, the Court permits big business and "wealthy corporations to use the Constitution as a shield to protect them from juries' full expressions of moral outrage.”256 Moreover, the Court's jurisprudence in this area leads many to question the overall interpretation of substantive due process in the new millennium. One must normatively consider who and what the Constitution protects. Professor Erwin Chemerinsky identifies what he terms a "cruel irony."257 "The principle that emerges is that too many years in prison for shoplifting does not violate the Constitution but too much money in punitive damages against a business for 'manslaughter' is unconstitutional.,258

In recent punitive damages cases including BMW and State Farm, the Court focused on the ratio between compensatory and punitive

253. Id. at 1088 .

254. Gary T. Schwartz, Deterrence and Punishment in the Common Law of Punitive Damages: A Comment, 56 S. CAL. L. REV. 133, 135 (1982).

255. Leo M. Romero, Punitive Damages, Criminal Punishment, and Proportionality: The Importance of Legislative Limits, 41 CoNN. L. REV. 109, 115 (2008).

256. Patrick H. Foley, Oil and Water: How the Polluted Wake of the Exxon Valdez has Endangered the Essence of Punitive Damages, 43 SufFOLK U. L. REV. 475, 494 (2010).

257. Chemerinsky, supra note 202, at 1051.

258. Id. 
damages. $^{259}$ The Eighth Amendment jurisprudential analysis pays no attention to the ratio between the state recidivist enhancement and the original punishment for the underlying criminal offense. ${ }^{260}$ Proportionality review for actual individuals is virtually nonexistent in noncapital cases, ${ }^{261}$ while strict proportionality review is applied to evaluate fairness for big business.

Another normative critique is based on the fact that the Court reviews punitive damages awards de novo. ${ }^{262}$ The reasoning advanced by the Court for de novo review of a punitive damages award is that it is essentially a question of law and not fact. ${ }^{263}$ However, when the Court analyzes criminal punishment, it tends to give significant deference to state legislatures. ${ }^{264}$ While big business and wealthy corporations have political capital at all levels of government, prisoners and ex-offenders have virtually no political power. ${ }^{265}$ Thus, it would seem logical to give equal or greater constitutional protection through application of stricter scrutiny to policies that affect individuals compared to those that affect big business, unless fairness is a right now enjoyed only by wealthy corporations in American jurisprudence.

\section{THe CHALLENGE}

\section{A. Substantive Due Process Analysis}

In light of the principles and framework crafted in BMW, many occupational licensing restrictions should be found violative of due process and therefore invalid. This is not to say that in all situations occupational licensing restrictions will be found unconstitutional. But in the context of an offender who pleads guilty to a low-level, nonviolent crime, it appears elementary that in most circumstances a reviewing court will find not only a fair-notice violation but also that the civil penalty is unreasonable and grossly excessive.

\footnotetext{
259. Id. at 1063.

260. Id. at 1051.

261. See Rachel E. Barkow, The Court of Life and Death: The Two Tracks of Constitutional Sentencing Law and the Case for Uniformity, 107 MICH. L. REV. 1145, 1188 (2009) (discussing how noncapital defendants receive almost none of the benefits that capital defendants receive).

262. Cooper Indus. v. Leatherman Tool Grp., 532 U.S. 424, 436 (2001).

263. Id. at 437.

264. See Chemerinsky, supra note 202, at 1058-62 (noting that the Court's Eighth Amendment review of noncapital cases rarely results in a finding that state punishment is unconstitutional).

265. Id. at 1071.
} 


\section{Fair Notice}

Regarding notice, it is reasonable to say that many offenders pleading guilty to offenses do not receive adequate notice that their criminal conduct will trigger a variety of civil penalties. Using the principles established in $B M W$ to evaluate fair notice, ex-offenders do not have notice that their underlying criminal conduct will set in motion specific occupational licensing restrictions and that the severity of the restrictions are manifested in indeterminate eligibility, potential lifetime ban, and exclusion from a major economic sector of society.

As mentioned earlier, there are over 38,000 civil consequences of conviction nationwide, averaging 700 per jurisdiction. ${ }^{266}$ Approximately $65 \%$ of these penalties are employment related. ${ }^{267}$ These consequences of conviction are civil penalties that attach by virtue of a felony conviction. $^{268}$ Although not frequently visited as a constitutional issue for the Supreme Court, the existing legal treatment of these penalties is semantic. It appears from current legal doctrine that the nomenclature of "collateral consequences" puts these penalties outside of the constitutional reach of plea colloquies and, in many instances, the advice given by defense counsel in a criminal case. ${ }^{269}$ Although a plea of guilty must be at least voluntary and knowing to satisfy guaranteed protections under due process, ${ }^{270}$ collateral consequences of a conviction are typically not a penalty criminal defendants are constitutionally required to receive notice of through counsel or the trial court during a plea. ${ }^{271}$ Given this, most ex-offenders will not receive fair notice of collateral consequences due to the sheer volume of statutes and regulations disqualifying this group from obtaining licenses and employment opportunities. Furthermore, this particular demographic is undereducated, overcriminalized, and the most politically vulnerable group in American society today.

\footnotetext{
266. Gowen, supra note 34 .

267. Id.

268. Chin, supra note 36, at 253.

269. Jenny Roberts, The Mythical Divide Between Collateral and Direct Consequences of Criminal Convictions: Involuntary Commitment of "Sexually Violent Predators," 93 MinN. L. Rev. 670, 678-80 (2008).

270. Brady v. United States, 397 U.S. 742, 747 n.4 (1970).

271. Gabriel J. Chin \& Richard W. Holmes, Jr., Effective Assistance of Counsel and the Consequences of Guilty Pleas, 87 CORNELL L. REV. 697, 726 (2002).
} 
[Vol. 61

\section{Three Guideposts}

Under the $B M W$ framework, cases concerning occupational licensing restrictions based on nonviolent convictions may be challenged successfully. Evaluating the first guidepost, a trial court would determine the degree of criminal reprehensibility or blameworthiness underlying the defendant's conduct. ${ }^{272}$ Here, the more dangerous and frequent the defendant's conduct, the more liability society will assume. In $B M W$, the Court quoted proportionality language from the Eighth Amendment Supreme Court case of Solem v. Helm, "non-violent crimes are less serious than crimes marked by violence or the threat of violence."273 This quotation is important for two reasons: (1) it goes directly to the heart of the issue in this guidepost, namely that nonviolent crimes are less severe than violent crimes and should therefore be analyzed as less reprehensible, and (2) it freely utilizes dicta from the punishment cases to evaluate the fairness of punitive damages, which essentially formulated a neutral principle-a hybrid opinion composed of civil and criminal Supreme Court precedent. It created a flexible premise applicable in a number of constitutional questions. The Court also asserted that economic harm is less reprehensible than "indifference to or reckless disregard for the health and safety of others." 274 With this, it follows that economic harm is not equivalent to harms that are violent and reckless or that disregard the health and safety of others.

Assessing the second guidepost, ${ }^{275}$ the ratio of the severity of the consequences on the individual to the actual and potential harm on victims and potential victims, requires proportionality review. This notion is easily translated. In the case of nonviolent offenders, the harm stemming from statutory and regulatory exclusions on the ex-offender may outweigh the actual and potential harm on victims and potential victims. As a general matter, many nonviolent offenses are considered victimless crimes and so harm to victims would be low. ${ }^{276}$ Of course,

272. $\quad$ BMW of N. Am. v. Gore, 517 U.S. 559, 575-80 (1996); see also supra Part IV.B.1.

273. BMW. 517 U.S. at 576 (quoting Solem v. Helm, 463 U.S. 277, 292-93 (1983)) (internal quotation marks omitted).

274. Id.

275. Id. at 580-83; see also supra Part IV.B.2.

276. Although I do recognize that drug offenses have potential victims, and the amount of drugs could have numerous harms associated with potential victims, I do not subscribe to that argument because use of controlled substances is a free-will choice in the first instance. Moreover, American criminal law does not recognize a duty of care for the health and safety of unrelated friends, extended family, or strangers. 
there are those extreme cases where a nonviolent crime causes substantial economic harm to a real victim, such as in Ponzi schemes and identity theft. For purposes of this thesis, however, the focus is on runof-the-mill, low-level, nonviolent drug offenses. Utilizing the constitutionally tolerated ratios set forth by the Court in State Farm and Exxon, a nonviolent felony conviction that triggers a lifetime occupational licensing restriction would be constitutionally impermissible. A durational requirement prior to being considered eligible for a license may be allowed. However, the duration ought not exceed single-digit ratios because the Court may find such government action grossly excessive.

Finally, the third $B M W$ factor, the way in which the punitive damages award compares with criminal or civil penalties that have been or could be imposed for comparable misconduct, ${ }^{277}$ allows for great flexibility. Comparisons could be made with the same jurisdiction, different American jurisdictions, and foreign jurisdictions on the issue. Collateral consequences vary across state lines as states administer them differently, apply different time limits, and have a different administrative protocol for the restoration of rights. Cross-nationally comparing occupational licensing statutes would benefit any claim.

\section{a. A Hypothetical—Wisconsin and Private Security Guards}

To better illustrate how a challenge to an automatic license disqualification would be levied and possibly analyzed, take the following hypothetical based on the Wisconsin private detective, investigator, and security personnel statute. This section discusses the arguments that could be made by challengers as well as those that the state would likely put forth were a challenge brought. The statute states, "An individual who has been convicted in this state or elsewhere of a felony and who has not been pardoned for that felony is not eligible for a license under this section."278 The statute also prohibits individuals convicted of unpardoned felonies from working for a private detective agency that does business in Wisconsin as a supplier of private security guards in a variety of different contexts including patrolling businesses, stadiums, hospitals, colleges, and similar activities. ${ }^{279}$

277. BMW, 517 U.S. at 583-85; see also supra Part IV.B.3.

278. Wis. STAT. ANN. § 440.26(2)(c)2 (West 2012).

279. Id. § 440.26(5)(c), (5m)2. 
I chose this statute for a number of reasons. First, the statute in its current form has been in existence since $1996 .{ }^{280}$ Prior to that, the statute included a five-year waiting period for those convicted of a felony to become eligible for the license. ${ }^{281}$ This demonstrates the way the legislature intentionally excluded unpardoned ex-offenders from this occupation for a lifetime rather than a period of time. It is also important that this statute is automatic upon conviction. There is no first-offender exception to the rule. In other words, once a felony conviction is announced and recorded, an individual is automatically ineligible for this license unless pardoned by the governor. In Wisconsin, there have been a total of fifty-two pardons since 2001, excluding the eighty-five pardons granted by Governor Doyle in 2010 after announcing he would not run for reelection. ${ }^{282}$ In addition, this statute is the classic blanket prohibition against felony offenders, meaning that there is no distinction between classifications of crimes in determining eligibility. An individual convicted of robbery is treated the same as an individual convicted of possession of a narcotic. Moreover, the statute and accompanying regulations fail to mention any right to judicial review upon agency denial. ${ }^{283}$ There is also no provision in the statute calling for review by an administrative law judge. ${ }^{284}$ Instead, eligibility decisions are within the exclusive discretion of the department. ${ }^{285}$ The statute also does not require any relationship between the crime of conviction and the job duties of a security guard or private detective. ${ }^{286}$ The actual occupation of private security guard is critical to the analysis because these jobs form a major employment sector in the national and local economies, and are expected to grow. ${ }^{287}$ I chose this statute due to the prevalence of jobs available in this sector of the economy and the range of employment

\footnotetext{
280 See S.B. 597, 1995-96 Leg., Reg. Sess. § 19 (Wis. 1996) (amending language in WIS. STAT. ANN. § 440.26(2)(c)).

281. See id.

282. Donald Leo Bach, To Forgive, Divine: The Governor's Pardoning Power, Wis. LAW., Feb. 2005, available at http://www.wisbar.org/AM/Template.cfm?Section=Current_Issue1\&TEMPLATE $=/ \mathrm{CM} /$ ContentDisplay.cfm\&CONTENTID=39460 (compiling data from Wisconsin Secretary of State and reports filed to state senate from 1979-2004).

283. See Wis. STAT. ANN. § 440.26 (2)(c).

284. See id. The administrative law judge is an attorney designated by the department general counsel. WIS. ADMIN. CODE SPS § 1-08(2) (2012).

285. See Wis. Stat. AnN. § 440.26.

286. Id. § 440.26(2)(c)2.

287. See Security Guard Employment Before and After 2001, IsSUES LABOR STATS, Aug. 2007, http://www.bls.gov/opub/ils/pdf/opbils6l.pdf (showing a trend of increase in security guard employment from 2000-2006).
} 
opportunities this license covers. Employment in this industry skyrocketed after September $11 \mathrm{th},{ }^{288}$ and in Wisconsin specifically it is projected that this sector will continue to grow despite the recession. ${ }^{289}$

In this hypothetical, the challenger is a male convicted of simple possession of oxycodone. In Wisconsin, an individual pleading guilty for first time simple possession of oxycodone is guilty of a Class I felony. ${ }^{290}$ An individual convicted of a Class I felony is exposed to "a fine not to exceed $\$ 10,000$ or imprisonment not to exceed 3 years and 6 months, or both." ${ }^{291}$ It is the lowest level felony in the Wisconsin criminal classification system. ${ }^{292}$ For purposes of this hypothetical the challenger is a first-offender with no prior arrests who received a sentence of six months in prison plus \$250 in fines. The sentence was completed five years ago. ${ }^{293}$

After applying and being denied a license without a hearing, the individual files a claim in state court (or federal) against the Commissioner of the Department of Regulation and Licensing challenging the denial of the license. The primary allegation in the complaint asserts a due process violation insofar as he was denied fair notice. More specifically, the petitioner argues that he is being denied a liberty interest in the opportunity and ability to engage in a common occupation without constitutionally sufficient notice of the exposure to penalties and the severity of those penalties. The complaint further alleges that the department's licensing requirement is grossly disproportionate and excessive in relation to the underlying criminal offense. A complaint should also include allegations of a violation of any codified employment discrimination statutes. In the case at bar, the challenger need not include an allegation of a violation of section 111.31(1)-(3) of the Wisconsin Fair Employment Act (WFEA) ${ }^{294}$ prohibiting discrimination against an individual with a felony conviction. This is because WFEA contains an exception to the rule in section

288. Id.

289. State of Wis. Dep’t of Workforce DeV., Office of Econ. Advisors, 2008-2018 OCCUPATIONAL PROJECTIONS, http://dwd.wisconsin.gov/oea/employment_projections/Wisconsin/lt_ occ_detail.xls (last visited Oct. 10, 2012).

290. Wis. STAT. ANN. § 961.41(3g)(am).

291. Id. § 939.50(3)(i).

292. Id.

293. The five-year mark is significant as the older version of the statute permitted licensing of felons as long as their conviction was five years old. S.B. 597, 1995-96 Leg. Reg. Sess. § 19 (Wis. 1996).

294. Wis. StaT. ANN. § 111.31(1)-(3) (West 2002 \& Supp. 2011). 
111.31, which directly states that WFEA is inapplicable to claims of discrimination in the licensing of private security persons. ${ }^{295}$

Generally, the complaint must also assert important facts and supporting information. The pleadings must include the conviction, the circumstances surrounding the conviction, the sentence issued, and the duration of time that has elapsed since the sentence was completed. These facts are necessary to show the nature and gravity of the offense so as to demonstrate the lack of a relationship between the underlying criminal conduct and the excessiveness of the statute. Such facts may also demonstrate the likelihood of reoffending. The claim must also include information regarding the number of jobs available to the holder of a private security guard license in the national and state economies and the expected growth of these jobs to establish the magnitude of the lifetime loss of opportunity.

The analysis begins by evaluating the "degree of reprehensibility of the defendant's conduct." 296 This assessment is subjective. However, $B M W$ gives a reviewing court some guidance. First, the Court in $B M W$ stressed the principle "that punishment should fit the crime"297 and that penalties issued should "reflect the enormity of his offense."298 Thus, on the scale of blameworthiness simple possession of a Schedule II narcotic is marginally reprehensible because the harm caused is (a) theoretical and (b) without a victim. This is reflected by the classification of the crime as a Class I felony. The first guidepost also considers whether the defendant is a recidivist. In this hypothetical the challenger is not a recidivist, making him still only minimally blameworthy. If he were a recidivist with similar nonviolent offenses, the number of convictions would become relevant to his degree of reprehensibility. The result of the evaluation of the first guidepost demonstrates that the defendant's conduct is minimally reprehensible.

Next, the Court assesses the ratio of the severity of the consequences on the individual versus the actual and potential harm on victims and potential victims. ${ }^{299}$ The second guidepost encompasses a strict proportionality assessment. ${ }^{300}$ The severity of the statute, namely barring

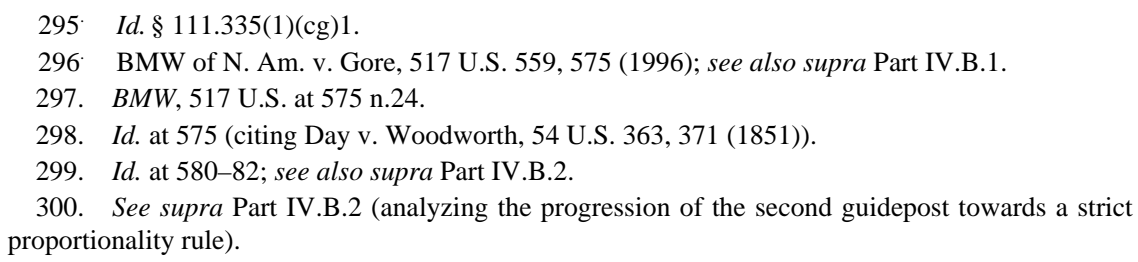


an entire class of people from the opportunity to engage in a common occupation such as a private security guard for an indefinite duration, is quite severe. This type of license is necessary for a number of jobs in the national economy including private security guards employed by a number of state agencies, different private contracting agencies, retail and department stores, parking lots, and the like. The individual's offense, possession of an illegal substance, is minimal. The crime itself does not have a human victim or potential human victim. The only victim is society, which suffers on a theoretical level from the offender's breach of the criminal law in that specific jurisdiction. In assessing the challenger's criminal sentence and employment sanctions, it is obvious that the ratio exceeds double digits. Strictly, the criminal sentence lasted six months and the Wisconsin statute requires a lifetime ban. This ratio clearly exceeds the double-digit threshold, obviously beyond the "outermost limits of the due process guarantee."301 When reminded of the degree of reprehensibility of the challenger, the irrationality of the statute crystallizes.

Finally, the third factor, how the punitive damages award compares with criminal or civil penalties that have been or could be imposed for comparable misconduct, allows for cross-jurisdictional analysis. ${ }^{302}$ Comparing the criminal sanctions the individual would receive is an exercise in futility because he already received the criminal penalty permitted by statute in that jurisdiction. The individual is challenging the civil disqualification stemming from his conviction, thus, a fair comparison would be with different state licensing requirements for the same license. In comparing a neighboring state's statutory requirements, Illinois allows for some leeway. In Illinois, a felony conviction is not an absolute bar to acquiring the license, and completed sentences over ten years old are not considered in the determination. ${ }^{303}$ In Connecticut, when an individual is denied a private detective or security guard license based on a felony conviction, he is statutorily permitted to appeal the issue to the Commissioner. ${ }^{304}$ The comparison could extend across the fifty states to demonstrate the severity of the Wisconsin statutory licensing requirement. From this analysis it appears the licensing law is excessive.

\footnotetext{
301 State Farm Mut. Auto. Ins. Co. v. Campbell, 538 U.S. 408, 425 (2003).

302. BMW, 517 U.S. at 583-85; see also supra Part IV.B.3.

303. 225 ILl. CoMp. StAT. ANN. § 447 / 25-10(2)-(3) (West 2007).

304. Conn. Gen. Stat. AnN. § 29-154a(d) (West 2010) (private detective); id. § 29-161h(d) (West 2011) (security guard).
} 
While the $B M W$ framework has been criticized both legally and normatively, it does promote a higher level of scrutiny that may be applied in other contexts. After assessing the Wisconsin statute in light of a nonviolent, minimally reprehensible offense, it becomes apparent that the statute may be vague, too burdensome, overinclusive, and clearly excessive in many cases. In this vein, it is important that courts ensure evenhandedness in penalties levied by states for punishable criminal conduct. At the very least, courts ought to invoke principles of proportionality to maintain a fair and ordered system of justice.

\section{State Arguments}

The state likely would argue that it has a legitimate interest in preventing criminals from engaging in occupations affecting public welfare and safety. In essence, the state would argue for a presumption that convicted felons are untrustworthy, unlikely to rehabilitate, and lack good character. The state's argument would most likely fail for numerous reasons.

First, while it is true that the state has a duty to protect its citizens from those who endanger the public safety and welfare in the context of employment, it does not have a legislative mandate to enact blanket disqualifications on an entire class of persons without at least a reasonable relation to the interest the state desires to protect. ${ }^{305}$ This is equal protection and due process 101 . Activities associated with a private security guard include patrolling premises to maintain order, ensuring compliance with applicable rules and regulations, warning and ejecting troublemakers, guarding against theft, and assisting management. ${ }^{306}$ It begs the question, what is the relationship between these activities and possession of two Percocet pills? Again, our challenger was not convicted of manufacture, distribution, or sale, nor was he convicted of DUI or anything similar. It is difficult to find a relationship between possession and activities associated with the license.

Second, the state makes no distinction in the nature and degree of felony convictions. ${ }^{307}$ For the state, an individual convicted of murder in

\footnotetext{
305. Richard B. Saphine, Equal Protection, Rational Basis Review, and the Impact of Cleburne Living Center, Inc., 88 KY. L.J. 591, 597 (2000).

306. Guard, Security, DICTIONARY OF OCCUPATIONAL TITLES, http://www.occupationalinfo.org /37/372667034.html (last visited Nov. 2, 2012).

307. See Wis. StAT. ANN. § 111.335(1)(g) (West 2012); see also supra note 293 and
} 
the first degree faces the same disqualification as the individual convicted of possessing one and one-half ounces of marijuana or even two Percocet pills. The two classes of crime are treated the same. This is so even though the state has enacted different criminal penalties for the two crimes, and the defendant convicted of murder or robbery causes more harm to society and is thus more criminally culpable. Moreover, an across-the-board exclusion fails to account for individual characteristics such as age, subsequent employment, and educational experience, which are factors that have been statistically shown to reduce criminal recidivism. ${ }^{308}$

Finally, the irrationality of the statute is crystallized when compared to the licensure requirements to practice medicine or law, which are professions with greater connections to the public welfare and safety. In many jurisdictions a felony conviction is not an absolute bar to the practice of law, and there is no bar to the practice of medicine in Wisconsin based strictly on a felony conviction. ${ }^{309}$

\section{COUNTERARGUMENTS}

While this approach is a workable solution, it is far from perfect. Three important counterarguments may be addressed up front. The first is a separation of powers argument asserting that such decisions regarding state licensing ought to be left to the state legislatures. The second argument asserts that the Eighth Amendment may be better suited for this type of challenge. The final criticism argues that the constitutional claim ought to be a Sixth Amendment ineffective assistance of counsel claim.

\section{A. Separation of Powers}

One could argue that this issue is better suited for the legislature as it is this branch of government that reflects the will of the people and contemplates reforming licensing in its individual state. This argument brings to the fore issues of separation of powers. Under this argument,

accompanying text.

308. Silva, supra note 52, at 162-63.

309. See WIS. STAT. ANN. § 448.05 (referencing section 111.335(c)(1) requiring that the disqualifying felony "substantially relate to the circumstances of the particular job or licensed activity”). 
the approach advocated in this Article would promote unwarranted judicial activism. While there is merit in this argument, it is important to remember that the judiciary serves as a check on the other two branches of government, as was intended under separation of powers. Understanding that the legislature is the proper place for legislative reform, the judiciary is still responsible for ensuring that individual interests and rights are afforded requisite constitutional protections. ${ }^{310}$ It is within the province of the judiciary to make certain that arbitrary, capricious, and unreasonable government conduct is checked, and the life, liberty, and property of individuals are afforded the appropriate degree of due process. Deference to the legislature is not always the correct judicial response. The Court has taken the liberty to invalidate punitive damage awards issued by juries against corporate entities ${ }^{311}$ and state laws failing to provide sufficient judicial review of punitive damages. ${ }^{312}$ Will the Court offer the same protection to individuals faced with the deprivation of their ability to work, go to school, or engage in civic life? This is a normative consideration that will have to be addressed by the courts or the people.

As a general matter, felons lack both political and social capital. Felon disenfranchisement is the subject of numerous scholarly articles as well as quantitative and qualitative studies. According to stigma theory, ex-offenders are denied the right to vote because they are deemed "morally incompetent, unredeemable, and likely to recidivate."313 Originating from European Enlightenment thinkers such as Hobbes and Rousseau, "civil death" required convicts be to be treated as "lawful enem[ies] of the commonwealth" 314 and separated from the citizenry for violating the social compact. ${ }^{315}$ In America, reasons for precluding felons from voting include preserving the "purity of the ballot box,"

310. See Richard B. Stewart \& Cass R. Sunstein, Public Programs and Private Rights, 95 HARV. L. REV. 1193, 1260 (1982) (discussing one theory of the role of the judiciary).

311. Exxon Shipping Co. v. Baker, 554 U.S. 471, 514 (2008); State Farm Mut. Auto. Ins. Co. v. Campbell, 538 U.S. 408, 429 (2003); BMW of N. Am. v. Gore, 517 U.S. 559, 574-75 (1996); see also Philip Morris USA v. Williams, 549 U.S. 346, 357-58 (2007) (choosing to not decide issue of whether punitive damages were excessive because its decision to remand the case to the Oregon Supreme Court to better apply its guideposts could result in a new trial and new punitive damage award).

312. Honda Motor Co. v. Oberg, 512 U.S. 415, 434 (1994).

313. Afi S. Johnson-Parris, Note, Felon Disenfranchisement: The Unconscionable Social Contract Breached, 89 VA. L. REV. 109, 123 (2003).

314. See THOMAS HobBes, LeVIATHAN 248-49 (1651).

315. Jean Jacques Rousseau, The Social Contract 31-32 (Charles Frankel ed., Hafner Publ'g Co. 1947) (1762). 
weakening law enforcement institutions, and protection of the welfare of communities. ${ }^{316}$

Professors Uggen and Manza estimate that 5.3 million adults were legally disenfranchised by virtue of conviction in $2000 .^{317}$ Three-fourths of this population were either under community supervision or had completed their sentence, yet they were still disenfranchised by state statute. $^{318}$ Professors Uggen and Manza conclude that disenfranchisement has affected "seven U.S. Senate races from 1970 to 1998," particularly in states with a close election and a number of disenfranchised persons in their jurisdiction. ${ }^{319}$ At last count, 2\% of the general population and $13 \%$ of black males were disenfranchised as a result of criminal conviction. ${ }^{320}$

Statutory prohibitions on voting reduce turnout in many communities, especially minority communities. ${ }^{321}$ In this respect, democratic decision-making with regard to policies adversely affecting ex-offenders is impaired: "The exclusion of ex-offenders from full participation in political life affects the quality of the decision-making with regard to such issues by community residents themselves.”322 Justice Thurgood Marshall recognized the importance and value of the inclusion of ex-offenders in the political process as he asserted,

[Ex-offenders] are as much affected by the actions of government as any other citizens, and have as much of a right to participate in governmental decision-making. Furthermore, the denial of the right to vote to such persons is a hindrance to the efforts of society to rehabilitate former felons and convert them into law-abiding and productive citizens. ${ }^{323}$

316. Marc Mauer, Mass Imprisonment and The Disappearing Voters, in INVISIBLE Punishment: THE COllateral CONSEQUENCES OF MASS IMPRISONMENT 50, 54 (Marc Mauer \& Mesa Chesney-Lind eds., 2002) (citing Washington v. State, 75 Ala. 585 (1884)).

317. Christopher Uggen et al., Citizenship, Democracy, and the Civic Reintegration of Criminal Offenders, 605 AnNals AM. ACAD. POL. \& SoC. SCI. 281, 287 tbl.1 (2006).

318. Id.

319. Mauer, supra note 316, at 53 (citing Uggen et al., supra note 317).

320. Id. at 51

321. Aman McLeod et al., The Locked Ballot Box: The Impact of State Criminal Disenfranchisement Laws on African American Voting Behavior and Implications for Reform, 11 VA. J. SOC. POL'Y \& L. 66, 80 (2003). Moreover, the likelihood of voting declines at a greater rate for blacks overall compared to whites in states with restrictive disenfranchisement laws. Id.

322. Regina Austin, "The Shame of It All": Stigma and the Political Disenfranchisement of Formerly Convicted and Incarcerated Persons, 36 Colum. HuM. RTS. L. ReV. 173, 183 (2004).

323. Richardson v. Ramirez, 418 U.S. 24, 78-79 (Marshall, J., dissenting) (quoting Memorandum of the Secretary of State of California in Opposition to Certiorari, Cnty. Clerks \& 
Without social capital, the cycle of deprivation continues with exoffenders being the hardest hit.

Although legislators and ex-offenders have much in common by way of reforming penal policy, albeit for different reasons, it is unlikely that a true coalition will be built. Legislators hoping for increased revenue through a productive, employed citizenry and ex-offenders needing occupational opportunity, will doubtful unite to reform current occupational licensing schemas. The reason for this skepticism stems from the fact that legislators are preoccupied with election risks, and being associated as a champion of ex-offender employment could make constituents uneasy about their legislators' stance on crime. ${ }^{324}$ Despite state and federal studies on incarceration costs and recidivism, retrenchment from escalating criminal penalties is unlikely to take place in a legislative forum until courts begin to assess the constitutionality of employment consequences of conviction and signal a need for change.

\section{B. Eighth Amendment}

Another counterargument is that the Eighth Amendment is better suited to address the issue of occupational consequences because criminal conduct underlies the government deprivation. This argument, while important and potentially true, is flawed. First, collateral consequences of conviction are civil penalties and are unlikely to be deemed an extension of criminal punishment. This calls for a different mode of analysis the Eighth Amendment cannot provide. Moreover, the Court's tortured history with proportionality and prison sentences has thus far resulted in a line of precedent that offers almost no protections against excessive prison sentences but offers significant protection against excessive punitive damage awards. ${ }^{325}$ The Court has been hesitant in the application of proportionality in evaluating sentences and has often regressed from any asserted principles defending an individual prisoner's Eighth Amendment right against excessive penalty. ${ }^{326}$ Under Eighth Amendment jurisprudence, collateral consequences are likely to have a mixed outcome at best.

Registrars of Voters v. Ramirez, No. 73-324) (internal quotation marks omitted).

324. See Catherine Carpenter, Legislative Epidemics: A Cautionary Tale of Criminal Laws that Have Swept the Country, 58 BufF. L. REV. 1, 35-36 (2010); Gershowitz, supra note 115.

325. Chemerinsky, supra note 202, at 1051.

326. See supra note 261 and accompanying text. 


\section{Sixth Amendment}

In light of the Supreme Court's decision in Padilla v. Kentucky, ${ }^{327}$ reentry scholars are arguing to extend the Sixth Amendment right to counsel to other types of collateral consequences of conviction. ${ }^{328}$ This position appears to be a logical extension of Padilla; however, it may not be that simple. There are numerous hurdles to overcome.

The principal issue is the collateral consequences rule and its history in conjunction with the Sixth Amendment right to counsel. The collateral consequences rule states:

For purposes of determining whether a trial court has complied with its duty under the Due Process Clause to ensure that a guilty plea is knowing, voluntary, and intelligent, the Supreme Court has distinguished between direct consequences, which must be explained to the defendant, and collateral consequences, which the plea court has no duty to explore.

Direct consequences include the maximum term of imprisonment and fines for the crime charged. ${ }^{330}$ Collateral consequences, on the other hand, include parole and probation issues, civil commitment and forfeiture, habitual offender statutes, registration requirements, disenfranchisement, ineligibility to serve on a jury, and loss of professional licenses. ${ }^{331}$ All federal circuit courts of appeal except the Eighth and the Federal Circuit accept the rule, as do thirty-five state jurisdictions. $^{332}$ While the Padilla Court found deportation to be directly connected to a criminal conviction, ${ }^{333}$ it is unlikely that occupational licenses will be given the same treatment. The issue of deportation has invited a range of opinions on how removal as the result of criminal

327. 130 S. Ct. 1473, 1486-87 (2010) (holding that a criminal defense attorney's failure to advise his noncitizen client regarding the deportation consequences of a plea of guilty that would result in criminal conviction violated the Sixth Amendment's guarantee of effective assistance of counsel).

328. Margaret Love \& Gabriel Chin, The "Major Upheaval" of Padilla v. Kentucky: Extending the Right to Counsel to the Collateral Consequences of Conviction, 25 CRIM. JUST. 36, 41-42 (2010).

329. Chin \& Holmes, supra note 271, at 704.

330. Id. (citing United States v. Salmon, 944 F.2d 1106, 1130 (3d Cir. 1991)).

331. Id. at 705-06.

332. Id. at 706-08. The state jurisdictions include Alabama, Alaska, Arizona, California, Connecticut, Delaware, Florida, Georgia, Idaho, Illinois, Indiana, Iowa, Kansas, Maine, Maryland, Massachusetts, Michigan, Minnesota, Missouri, Nevada, New Hampshire, New Jersey, New Mexico, New York, North Carolina, North Dakota, Pennsylvania, Rhode Island, South Carolina, South Dakota, Tennessee, Texas, Utah, Washington, and Wisconsin. Id.

333. Padilla v. Kentucky, 130 S. Ct. 1473, 1486-87 (2010). 
conviction should be treated even in those jurisdictions that have adopted the collateral consequences rule. ${ }^{334}$

The sheer number of civil penalties in each jurisdiction may also dissuade courts from imposing an affirmative duty on defense counsel to warn their clients of all collateral consequences. While the ABA recommends that defense counsel warn their clients of these civil penalties, ${ }^{335}$ the Supreme Court has asserted that these ABA recommendations are only guides and are not binding on the courts. ${ }^{336}$

It is important to mention that the Padilla Court dissenters, Justices Scalia and Thomas, may have joined the majority had Padilla grounded his constitutional claim in due process. ${ }^{337}$ For Justice Scalia, the text of the Sixth Amendment guarantees a right to counsel in all criminal prosecutions and not in all matters collateral to criminal prosecutions. ${ }^{338}$ For constitutional textualists, this line of reasoning makes perfect sense.

The argument made by reentry scholars that the Sixth Amendment is the proper vehicle to challenge collateral consequences is both salient and legally sound, but it is only one tool in the reentry toolbox. This article advocates for yet another claim for individuals challenging the constitutionality of civil penalties, occupational licenses in particular, triggered by a criminal conviction.

\section{VII.CONCLUSION}

While the fate of ex-offenders is not at the top of the legislative priority list of state governments or Congress, expenditures on corrections is gaining public attention. We as a country can no longer afford to pay for the imprisonment of nonviolent offenders. One method to reduce the price tag is to prevent recidivism through occupational opportunity. With the ever expansive, overinclusive web of collateral consequences triggered by conviction, such opportunity is dangerously low, forcing states to continue to pay the price for individual recidivism. Understanding that support for repealing professional licensing restrictions for felons is a bullet in any legislators' political future, the

\footnotetext{
334. Chin \& Holmes, supra note 271, at 708.

335. ABA STANDARD FOR CRIMINAL JUSTICE 19-2.3 (3d ed. 2004), available at http://www. americanbar.org/Publications/criminal_justice_section_archive/crimjust_standards_collateral_blk.ht $\mathrm{ml} \# 2.3$.

336. Strickland v. Washington, 466 U.S. 668, 688 (1984).

337. See Padilla, 130 S. Ct. at 1496 (Scalia, J., dissenting) (stating the Due Process Clauses are more appropriate than the Sixth Amendment for Padilla's complaint).

338. Id. at 1494.
} 
courts may have to step in to push state legislators in the direction of repealing, or at the very least modifying, these disqualifications so that ex-offenders may support themselves, their families, and stay out of state and federal jails and prisons.

Although jurisprudence in the area of collateral consequences is sparse and at times contradictory, the Supreme Court has developed a framework that will lend itself to a fair evaluation of occupational licensing restrictions in the new millennium. This BMW framework, although heavily criticized, is a starting point in the analysis of the civil penalties associated with criminal convictions. Hopefully, the argument advanced in this Article offers a different paradigm in which to frame the current discourse surrounding collateral consequences of conviction generally and occupational licenses specifically. What this Article does is utilize a heavily criticized Supreme Court opinion in a way that could help millions of American citizens. It also encourages the application of the neutral-principles epistemology in today's Court judgments. Scholars and advocates may look for next steps and additional challenges to occupational licensing restrictions rooted in constitutional law. Moving forward, it is important to consider that this demographic lacks access to many of the resources and institutional understanding that facilitates reforms necessary to ensure due process is respected and administered even-handedly.

This Article, if nothing else, hopefully adds to the reentry conversation by situating the problem in context and looking for a real solution with promise of success. Scholars' approach to constitutional challenges must be pragmatic and address practical realities. By advancing this framework, scholars will call for the Court to apply its doctrine evenhandedly to both real people and multibillion-dollar corporations. It is a stepping stone on a platform of reform necessary to reintegrate the most left behind in American society and save taxpayer dollars in a stale economy. The fight for second chances is proving to be a game of inches. 